Review

\title{
Bangladesh Sundarbans: Present Status of the Environment and Biota
}

\author{
Abdul Aziz ${ }^{1}$ * and Ashit Ranjan Paul ${ }^{2}$ \\ 1 Department of Botany, University of Dhaka, Dhaka 1000, Bangladesh \\ 2 Assistant Chief Conservator of Forests, Bangladesh Forest Department, Ban Bhaban, Agargaon, \\ Dhaka 1000, Bangladesh; E-Mail: aranjanpaul4158@gmail.com \\ * Author to whom correspondence should be addressed; E-Mail: dr.aziz.botany@gmail.com; \\ Tel.: +880-1914818448.
}

Academic Editor: Peter Saenger

Received: 2 March 2015 / Accepted: 29 June 2015 / Published: 10 July 2015

\begin{abstract}
The Sundarbans is a deltaic mangrove forest, formed about 7000 years ago by the deposition of sediments from the foothills of the Himalayas through the Ganges river system, and is situated southwest of Bangladesh and south of West Bengal, India. However, for the last 40 years, the discharge of sediment-laden freshwater into the Bay of Bengal through the Bangladesh part of the Sundarbans Mangrove Forests (BSMF) has been reduced due to a withdrawal of water during the dry period from the Farakka Barrage in India. The result is two extremes of freshwater discharge at Gorai, the feeding River of the BSMF: a mean minimum monthly discharge varies from 0.00 to $170 \mathrm{~m}^{3} \cdot \mathrm{s}^{-1}$ during the dry period with a mean maximum of about 4000 to $8880 \mathrm{~m}^{3} \cdot \mathrm{s}^{-1}$ during the wet period. In the BSMF, about $180 \mathrm{~km}$ downstream, an additional low discharge results in the creation of a polyhaline environment (a minimum of $194.4 \mathrm{~m}^{3} \cdot \mathrm{s}^{-1}$ freshwater discharge is needed to maintain an oligohaline condition) during the dry period. The Ganges water carries 262 million ton sediments/year and only $7 \%$ is diverted in to southern distributaries. The low discharge retards sediment deposition in the forestlands' base as well as the formation of forestlands. The increase in water flow during monsoon on some occasions results in erosion of the fragile forestlands. Landsat Satellite data from the 1970 s to 2000 s revealed a non-significant decrease in the forestlands of total Sundarbans by $1.1 \%$ which for the $6017 \mathrm{~km}^{2}$ BSMF is equivalent to $66 \mathrm{~km}^{2}$. In another report from around the same time, the estimated total forestland loss was approximately $127 \mathrm{~km}^{2}$. The Sundarbans has had great influence on local freshwater environments, facilitating profuse growth of Heritiera fomes (sundri), the tallest (at over
\end{abstract}


$15 \mathrm{~m}$ ) and most commercially important plant, but now has more polyhaline areas threatening the sundri, affecting growth and distribution of other mangroves and biota. Landsat images and GIS data from 1989 to 2010 at the extreme northern part of Khulna and Chandpai Ranges revealed the formation of a large number of small rivers and creeks some time before 2000 that reduce the $443 \mathrm{~km}^{2}$ forestland by $3.61 \%$, approximately $16 \mathrm{~km}^{2}$, and decreasing H. fomes by $28.75 \%$ and total tree cover by over $3.0 \%$. The number of the relatively low-priced plants Bruguiera sexangula, Excoecaria agallocha and Sonneratia apetala, has, on the other hand, increased. Similar degradation could be occurring in other ranges, thereby putting the survivability of the Bangladesh Sundarbans at risk. The growing stock of 296 plants per ha in 1959 had been reduced to 144 by 1996. Trend analysis using "Table Curve 2D Programme," reveals a decreased number of 109 plants by the year 2020. The degradation of the Bangladesh Sundarbans has been attributed to reduced sediment-laden freshwater discharge through the BSMF river system since commissioning the Farakka Barrage on 21 April 1975 in India. To reduce salinity and forestland erosion, the maintenance of sediment-laden freshwater discharge through its river system has been suggested to re-create its pre-1975 environment for the growth of $H$. fomes, a true mangrove and the highest carbon-storing plant of the Sundarbans. This may possibly be achieved by proper sharing of the Ganges water from the Farakka Barrage, forming a consortium of India, Nepal, Bhutan and China, and converting parts or whole of the Ganges River into water reservoir(s). The idea is to implement the Ganges Barrage project about $33 \mathrm{~km}$ downstream, dredging sediments of the entire Gorai River and distributaries in the Ganges floodplain, thus allowing uniform sediment-laden freshwater flow to maintain an oligohaline environment for the healthy growth of mangroves. The system will also create healthy hinterlands of the Ganges floodplain with increased crop production and revenue. The expenditure may be met through carbon trading, as Bangladesh is a signatory of the Copenhagen Accord, UN Framework Convention on Climate Change. The total carbon reserve in the BSMF in 2010 was measured at about 56 million metric tons, valued at a minimum of US\$280 million per year. The forest is rich in biodiversity, where over 65 species of mangroves and about 1136 wildlife species occur. The BSMF acts as a natural wall, saving property as well as millions of lives from natural disasters, the value of which is between 273 and 714 million US\$. A 15 to $20 \mathrm{~km}$ band impact zone exists to the north and east of the BSMF, with a human settlement of about 3.5 million that is partly dependent on the forests. Three wildlife sanctuaries are to the south of the BSMF, the home of the great royal Bengal tigers, covering a total area of about 1397 $\mathrm{km}^{2}$. Construction of a coal-fired power plant at Rampal will be the largest threat to the Sundarbans. It is a reserve forest, declared as a Ramsar site of international importance and a UNESCO natural world heritage site.

Keywords: The Sundarbans; mangroves; Heritiera fomes; forests; salinity; Ganges River; Farakka Barrage 


\section{Introduction}

Sundarbans is the current spelling of "Sunderbunds" by Walter Hamilton of the East India Gazetteer, meaning the "Forests of the Soondry" (now spelled "Sundri" meaning beautiful). The scientific name is Heritiera fomes, a dominant species of the Bangladesh part of the Sundarbans Mangrove Forests (BSMF) [1]. It is the largest contiguous tract of mangroves (Figure 1A,B) covering about 10,000 km² [2-4], but an area of $9277 \mathrm{~km}^{2}$ has also been reported [5]. Distribution of the BSMF tree species (forest types), the three wildlife sanctuaries and 55 compartments for administrative convenience of the BSMF are shown in Figure 1C. The recorded total area of the BSMF is about $6017 \mathrm{~km}^{2}$ determined from visual interpretation of multi-spectral SPOT satellite data [3]. Of the total area, about $4038 \mathrm{~km}^{2}$ is forestland and more than $115 \mathrm{~km}^{2}$ is marshes within a network of 450 rivers (Figure $1 \mathrm{C}$ ). The rivers constitute about $12,000 \mathrm{~km}$ of waterways whose area ranges from $1757 \mathrm{~km}^{2}$ [3] to $1864 \mathrm{~km}^{2}$ [1], in addition to small rivers and creeks. Changes in size of the various components are due to the dynamic nature of the Sundarbans and to other reasons, especially the tidal bores that may wash away forestland near the coast from time to time. Erosion is concentrated along the banks of major river channels and at the land-water interface at the Bay of Bengal [6], thereby decreasing the total BSMF. Studies, using Landsat satellite data over 40 years of the total Sundarbans from the 1970 s to 2000 s, revealed that during this period the forestlands increased by $1.4 \%$, but from the $1990 \mathrm{~s}$ to $2000 \mathrm{~s}$, the area decreased by $2.5 \%$ and the net loss was $1.1 \%$; i.e., equivalent to $110 \mathrm{~km}^{2}$ [4]. Approximately half of the loss occurred at the extreme southern edge of the BSMF along the coast of the Bay of Bengal where almost no compensating aggradation took place [4]. Out of the total loss, the Bangladesh part is likely to have experienced more loss due to sediment-laden freshwater diversion from Farakka Barrage since 1975. From the data, it appears that the Bangladesh Sundarbans has so far lost about $66 \mathrm{~km}^{2}$ of forestlands.

The BSMF occupies $4.2 \%$ of the total area of Bangladesh and constitutes $44 \%$ of the forest cover in the country [3]. In the last part of the 20th century, mangrove forests of many countries of the world have been reduced, and the current estimate of the world's stock is less than half of what it had once been [7] and the area that remains has been significantly degraded by increased salinity and pollution $[8,9]$. About $35 \%$ of mangroves were lost from 1980 to 2000 worldwide [10] and this loss is occurring at a faster rate than that of inland tropical forests and coral reefs [11]. Based on satellite data, it has been concluded that the remaining area is less than previously thought and is $12.3 \%$ smaller than the most recent estimate [12]. Eight causes have been identified [6], such as: (i) conversion to agriculture, shrimp farms, development, and human settlement; (ii) over-harvesting by grazing, browsing and lopping, and fishing; (iii) pollution; (iv) decline in freshwater availability; (v) flooding; (vi) reduction of silt deposition; (vii) coastal erosion and (viii) disturbances from tropical cyclones and tsunamis. Of the eight causes, the last six, particularly decline in freshwater availability and reduction of silt deposition, are the causes of degradation of the BSMF. Relative sea-level rise could be the greatest threat to mangroves [13]. Predictions suggest that $100 \%$ of the mangrove forests could be lost in the next 100 years if the present rate of loss continues [11]. 

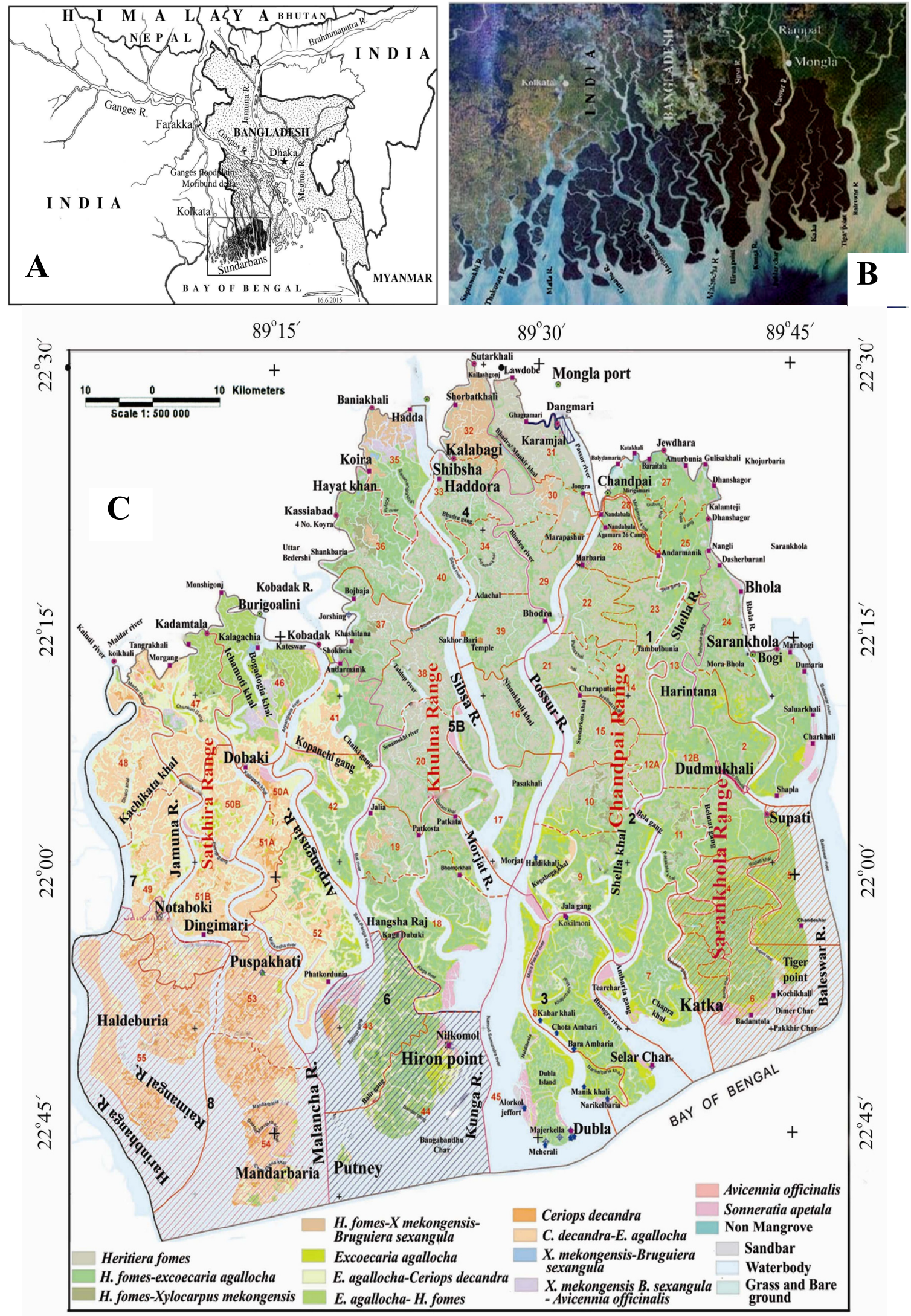

Figure 1. (A) Map of Bangladesh and parts of adjacent countries showing the origins of three mighty rivers; (B) The satellite image of total Sundarbans showing the network of rivers; the dark areas in the north and northeast are dominated by trees $>15 \mathrm{~m}$ high; (C) The Bangladesh Sundarbans. 
The reduced sediment-laden freshwater flow since the operation of Farakka Barrage in 1975, about $17 \mathrm{~km}$ from the Bangladesh border in India (Figure 1A), results in increased salinity in the BSMF, subsequently reducing the number of plants to about half in over 20 years [14]. Polyhaline (18\% to 30\%) conditions now prevail in more than half of the BSMF [3]. It has been concluded that much of the Sundarbans no longer provide an environment to which $H$. fomes are ecologically well suited [14]. In the early 1930s, S. J. Curtis observed that about half of the northern part of the BSMF was freshwater while the southern part was moderately saline [15], an environment potentially ideal for fostering a large stock of mangroves.

The review of the Bangladesh Sundarbans is aimed at understanding the causes of degradation of the environment and the biota, and developing a possible method towards its reclamation as a healthy forestland environment and the growth of Heritiera fomes (sundri), a mangrove species truly representative of this forest type.

\section{The Sundarbans and Their Origin}

The Sundarbans are a deltaic swamp forest, situated at $21^{\circ} 27^{\prime} 30^{\prime \prime}$ and $22^{\circ} 30^{\prime} 30^{\prime \prime} \mathrm{N}$ and $88^{\circ} 02^{\prime} 00^{\prime \prime}$ and $89^{\circ} 00^{\prime} 00^{\prime \prime} \mathrm{E}$ in the southwestern part (greater Khulna) of Bangladesh and to the south of 24 Parganas, West Bengal, India, having a total area of less than $10,000 \mathrm{~km}^{2}$, and containing the largest contiguous tract of mangroves in the world (Figure 1A,B). The Bangladesh part is at $21^{\circ} 38^{\prime} 10.18^{\prime \prime}$ and $22^{\circ} 29^{\prime} 51.65^{\prime \prime}$ $\mathrm{N}$ and $89^{\circ} 02^{\prime} 22.87^{\prime \prime}$ and $89^{\circ} 53^{\prime} 13.93^{\prime \prime}$ E from Harinbhanga River to the west of Baleswar River in the east (Figure 1C). The forestland surface is flat and ground elevation is about 0.9 to $2.11 \mathrm{~m}$ above the mean sea level [1].

Geologists believe that there was a general southeastern slope of the Bengal Basin during the tertiary period from the Himalayas, and the Ganges River started flowing down this slope creating a new delta through sediment deposition carried from the foothills of the Himalayas to the south of the Ganges floodplain, establishing the Sundarbans about 7000 years ago [16] (Figure 1A).

About 1000 years ago, the Bengal Basin tilted eastward, resulting in a raise of the western part of the delta and dissociating ancient branches of the Ganges from the present Indian Sundarbans [17]. This alteration caused reduced freshwater flow which in turn resulted in the creation of a saline water environment within the Indian forests [16]. The Bangladesh part had almost all the distributaries (except the one leading to Arpangachia and Sibsa River) mainly Gorai R. providing freshwater to the Passur and Sipsa Rivers in the BSMF.

\section{Present Status of the Bangladesh Sundarbans}

\section{Physical and Chemical Environment}

Climate: The SMF is situated in the warm, humid tropical region where mean annual minimum and maximum temperatures are 21 and $30{ }^{\circ} \mathrm{C}$, respectively, mean annual relative humidity varies from $70 \%$ to $80 \%$ and annual rainfall varies from 1640 and $2000 \mathrm{~mm} \mathrm{[3].}$

Hydrological regimes: Stream flow through Ganges, Bahmaputra and Surma-Kushiara Rivers originating from the Himalayas is the largest component (about 90\%) of freshwater sources in Bangladesh [18]. The rivers flow generally from north to south. Out of 15.5 million $\mathrm{km}^{2}$ of catchments, 
only about 7.5\% lie within Bangladesh and are distributed over most parts of the country (Figure 1). The Ganges R. sediment-laden freshwater discharge is the main source of water for the BSMF. The annual peak discharge varies from 31,600 to $76,000 \mathrm{~m}^{3} \cdot \mathrm{s}^{-1}$ and minimum discharges on many occasions were found to vary from 657 to $858 \mathrm{~m}^{3} \cdot \mathrm{s}^{-1}$ at Hardinge Bridge, about $185 \mathrm{~km}$ from BSMF (Figure 2B). The perennial freshwater bodies like "Beel Dakatia" in the moribund delta of the Ganges floodplain, to a limited extent, also constitute the hydrological regimes of the forests.

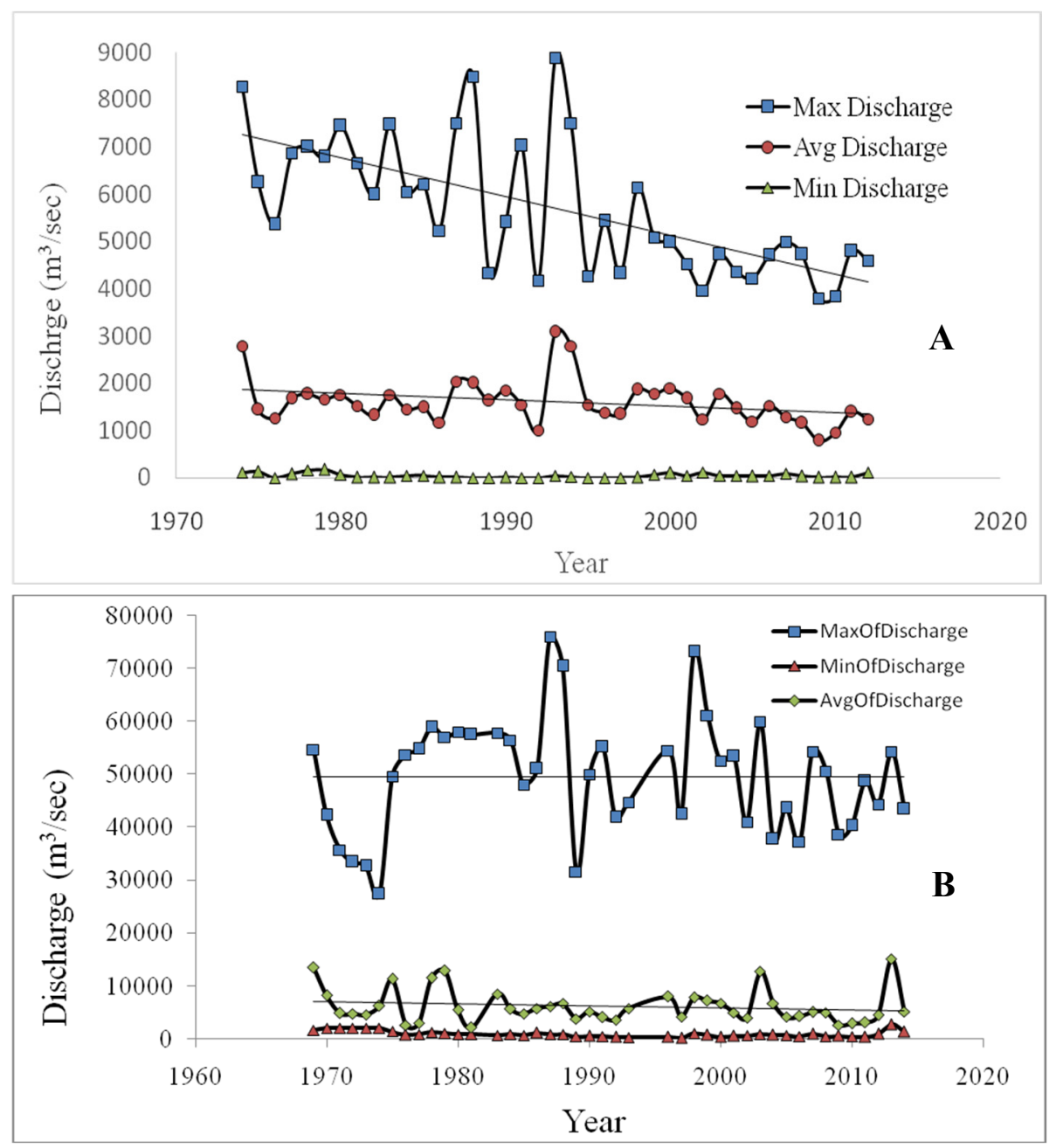

Figure 2. Yearly freshwater discharge patterns at Gorai Railway Bridge on Gorai River (A) and at Hardinge Bridge on Ganges River (B); the two peak max. discharges at both the stations are due to major floods in 1987 and 1998. Max. discharge means peak discharge of a monsoon month; average and minimum discharges are mean of 12-month values. Source: BWDB.

The discharge from the Ganges is particularly important for the BSMF. The Gorai River splits from the Ganges and the freshwater carried by it is distributed to Passur and Baleswar Rivers through Nabaganga and Madhumati, respectively (Figure 1A). About $85 \%$ of water passes through Passur system and only about $15 \%$ through Baleswar R., but the pattern has changed since diversion of water at Farakka Barage in India, $17 \mathrm{~km}$ upstream from the Bangladesh border, which was opened on 21 April 1975. The mean monthly available freshwater flow varies from 0.00 to $170 \mathrm{~m}^{3} \cdot \mathrm{s}^{-1}$ during the dry period and about 4000 to $8880 \mathrm{~m}^{3} \cdot \mathrm{s}^{-1}$ during the wet period at Gorai Railway Bridge, situated at about $160 \mathrm{~km}$ north of 
the BSMF (Figures 2A). The zero discharge occurred in two consecutive years, from January to April in 1995 and during March 1996, and only $0.62 \mathrm{~m}^{3} \cdot \mathrm{s}^{-1}$ was discharged during January 1997. This is the result of sediment-laden freshwater discharge to the BSMF. The max. discharge over 34 years formed a steep slope, indicating that water discharge through Gorai River is decreasing gradually due to sand bars starting from the mouth of the river.

Effect of Farakka Barrage on Salinity: Salinity increase in the BSMF occurred for two reasons: first, the diversion of freshwater at Farakka Barrage and second, by oceanic currents. The BSMF is now facing the two extremes. One immediate effect of the lower extreme is the increased salinity during the dry period. The salinity in the northern part of BSMF increased from $7.50 \%$ in 1968 to $12.50 \%$ in 1976 for March and to $18.50 \%$ in the month of May after two years of operation of the Farakka Barrage [19].

Oceanic current in the Bay of Bengal circulates in a clockwise direction during January to June when freshwater discharge from the upstream is zero to less than $174 \mathrm{~m}^{3} \cdot \mathrm{s}^{-1}$ in the BSMF. As a result, the marine water gets deep inside the forests, increasing the salinity. During July to December, the oceanic current circulates in an anticlockwise direction [20]. At this time, there is tremendous pressure of floodwater from upstream, possibly about $7000 \mathrm{~m}^{3} \cdot \mathrm{s}^{-1}$. As a result, there is limited saline water intrusion inside the BSMF; therefore, the forests near the coast remain moderately saline. Flooding for nearly four months every year reduces the salinity level greatly within the BSMF.

The BSMF is divided into three subsystems almost in a north-south direction where salinity varies due to hydrological regimes [21] (Figure 3A-B).

(a) The eastern subsystem is situated between Passur and Baleswar Rivers and receives freshwater from the Ganges through Gorai-Madhumati (which holds little freshwater during the dry period) and lower Meghna. The subsystem is of low salinity (Oligohaline, $<5 \%$ ).

(b) The central subsystem is located west of Passur and east of Sipsa. The Passur is connected with the Ganges through the Gorai River. However, the connection is blocked in the lean period by sand bars (chars). Due to reduced flow in the Ganges, the catchment area is extensively sedimented resulting in degradation of BSMF mainly due to increasing salinity (Mesohaline, $5 \%$ o to $<18 \%$ ).

(c) Western subsystem is located in the west of Sipsa River to the east of Raimangal-Harinbhanga River along the border. The subsystem originated from several perennial water bodies (moribund delta) (Figure 1). The Sipsa is connected with Passur which is already with low freshwater flow. Thus, the system does not receive any surface water from upstream during the dry period except local run off [21]. Seawater intrudes making the subsystem saline (Polyhaline, 18\%o to 30\%o).

In the northern part (eastern and central subsystem) of BSMF, water salinity varies from 4\%o to $28 \%$ in April and May, while in the post-monsoon it is $1 \%$ o to $9 \%$ [22]. In a period of eight months (from September to May), water salinity increased three to eight-fold, while the soil salinity increased two to five-fold.

Case studies since the 1930s to the 1990s revealed that the salinity in the BSMF has increased over time (Figure 3A,B). The BSMF was divided (curved slashed line in the Figure 3A) into freshwater (northern and eastern) and moderately saline (western and southern) zones in the early 1930s [15] but after 50 years and 10 years of operation of the Farakka Barrage, the BSMF has been divided into north-eastern freshwater, middle to southern moderately saline and western saline zones [14] (Figure 3A). After about 10 years, a largely different mesohaline zone was observed [23] (Figure 3B). However, the 
boundary is tentative varying with the seasonal variability of freshwater from upstream. Similarly, salinity of an area varies with the time of a year; peak salinity level occurs in April and May due to very low freshwater discharge (Figure 2A) and drops gradually in the soil and abruptly in water from June [24] (Figure 3C) due to huge freshwater discharge during the wet season (Figure 2A,B). The decrease in salinity is due to $112 \%$ freshwater flow in the monsoon and the increase is due to low flow; only $43 \%$ in the winter and summer compared to $85 \%$ pre- 1975 [21]. During monsoon and early autumn, almost the whole BSMF water remains in the range of mesohaline to lower range of oligohaline conditions, which move westward reducing the polyhaline zone that remains only near the coast. It has been estimated that about $60 \%$ of the BSMF in the west and south is polyhaline, while $35 \%$ is mesohaline in the middle and 5\% oligohaline in the eastern part for the rest of a year [21].
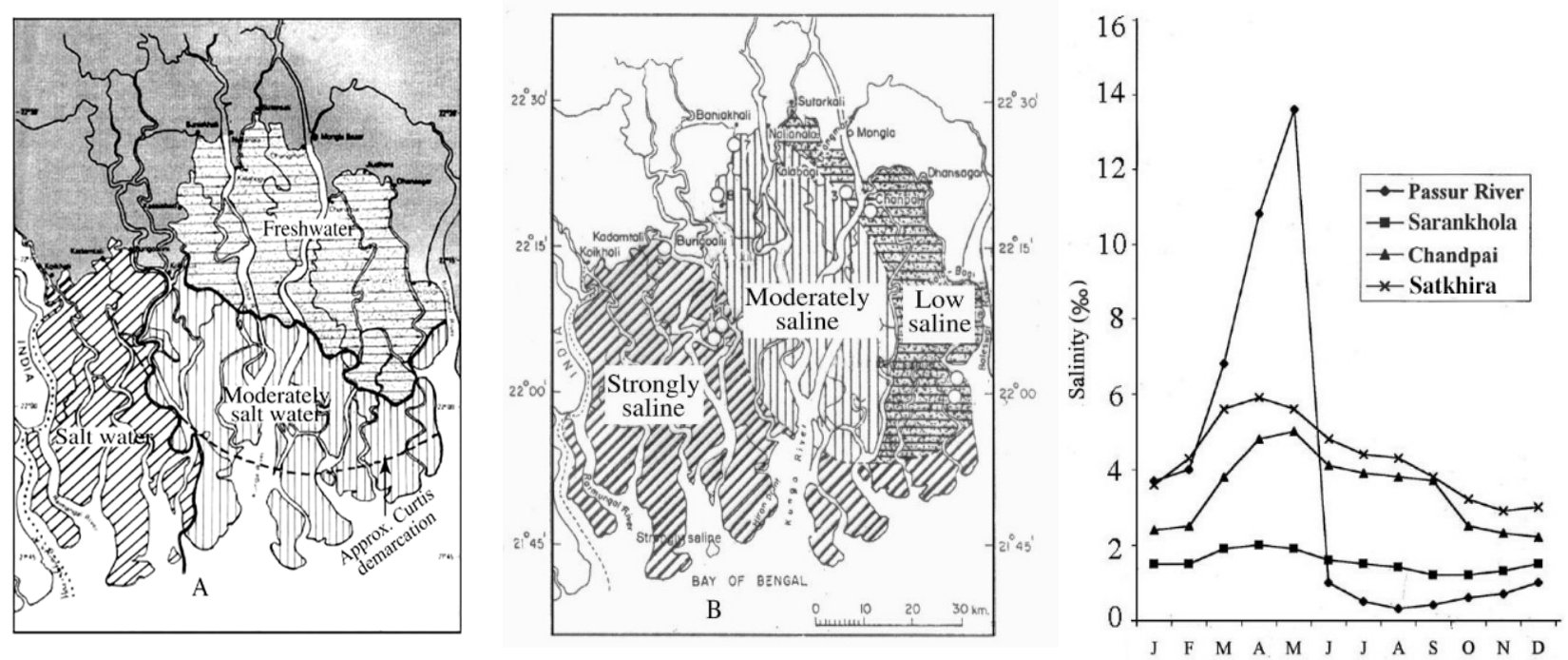

Figure 3. (A) Three saline zones of BSMF in 1983 [14] but divided in to two zones with approximate Curtis demarcation in 1930's, by a dotted line [15]; (B) A largely different distribution pattern of the three zones was found after about 10 years [23]; (C) Seasonal variation of salinity in the Passur River water (at Mongla) and surface soil of Sarankhola, Chandpai and Satkhira ranges in the late 1980s [24]. Figures used with permission.

Water: A direct relationship of the changed salinity (10.40\%o to $26.2 \%$ in March) with the TDS (8.03 to $>20 \mathrm{~g} / \mathrm{L}$ ) and conductivity (16.02 to $34.14 \mathrm{mS} / \mathrm{cm}$ ) was found in different locations [25]. Alkalinity ranged from 0.362 to $0.438 \mathrm{meq} / \mathrm{L}$ irrespective of salinity and tides. Similar is the case with $\mathrm{pH}$ that varied from 7.26 to 7.98. Variation of chemical factors between high and low tides at a set location were insignificant. As the forestlands are surrounded by rivers, canals and creeks, the tides and their chemistry have profound effects on the forest vegetation [21]. The river water salinity line has been found to be similar to the groundwater salinity line of the BSMF [26].

Tide: Depth and duration of tidal inundation is an important regulator of mangrove productivity [19,27]. Tides help in mixing vertical water columns, thereby providing nutrients and enriching water, providing vertical motion to the groundwater table that may transport nutrients to the root zones of the mangroves, transporting oxygen to the root system, etc. [27]. Tidal waves vary in different regions of BSMF according to the different hydrodynamic characteristics of rivers and cross channels. Mean tide height in the monsoon is at its highest (2.00 to $2.86 \mathrm{~m})$ and at its lowest (1.56 to $2.00 \mathrm{~m})$ in the dry period. A 
comparison of monthly tidal levels during a period of 20 years (1977 to 1997) at Hiron point and Mongla revealed that the mean tidal level at Hiron Point varied from $1.7 \mathrm{~m}$ in 1977 to $1.723 \mathrm{~m}$ in 1997, while at Mongla it varied from $2.233 \mathrm{~m}$ in 1977 to $2.356 \mathrm{~m}$ in 1997 (personal comm. Mrs. Shamsun Naher, BIWTA).

Soil: The forestland soil is grey in color, finely textured and the subsoil is stratified, compacted at greater depth. At the eastern part of the soil (having good supply of fresh sediments), the top $15 \mathrm{~cm}$ soil layer is soft and fertile, whereas in the western part (with little fresh sediments), the soil is a hard mass [28]. Na content of soils varies from 5.7 to $29.8 \mathrm{meq} / 100 \mathrm{~g}$, where the lower value is found in the eastern part. $\mathrm{Mg}$ varies from 4.1 to $9.9 \mathrm{meq} / 100 \mathrm{~g}$. Chloride is a dominant anion varying from 5.7 to $23.2 \mathrm{meq} / 100 \mathrm{~g}$, and the high concentration is found in the southern and western parts. Potassium content varies from 0.3 to $1.3 \mathrm{meq} / 100 \mathrm{~g}$. The high value of the $\mathrm{Na}$ and $\mathrm{Mg}$ hampers plant growth. Organic carbon and nitrogen are 0.62 and $0.05 \%$, respectively. Organic matter ranges between 4\% and 10\%. Soils are neutral to mildly alkaline $(6.5$ to $8.0 \mathrm{pH})$. The $\mathrm{pH}$ in depressions with high organic matter ranges from 5.3 to 6.4 [28].

Soil salinity in the mangroves is regulated by inundations, freshwater discharge, rainfall, soil types, topography, etc. BSMF soil salinity is low compared to other mangroves of the world (exceeding that of sea water) [19]. The soil salinity (upper $15 \mathrm{~cm}$ ) is lowest $(1.0 \%$ o to $4.5 \%$ ) in the monsoon but the peak (3.3\%o to $17.3 \%$ ) is found during the dry period [26]. Lowest salinity $(0.4 \%$ ) in the Chandpai range (oligohaline) and highest (6.3\%o) in the Sarankhola range (at Katka) was observed during the last week of March 2010 [29]. Subsurface soil salinity is higher due to leaching or recharge of groundwater by the tidal water [21] and that the salinity of surface water salinity line and groundwater salinity line were similar [26]. The tap root of trees is thus exposed to high salinity.

Effect of Farakka Barrage on the structure of the BSMF: The very low (sometimes nil) discharge in the dry period results in low sediment deposit around forestland situated about $160 \mathrm{~km}$ away. In the flood period, on the other hand, around $4000 \mathrm{~m}^{3} \cdot \mathrm{s}^{-1}$ to $8880 \mathrm{~m}^{3} \cdot \mathrm{s}^{-1}$ water is discharged at Gorai River, eroding river banks and margins of forestland causing BSMF to be vulnerable to wave or tidal activity. An increase of $112 \%$ peak flow in the monsoon has been recorded [21]. Erosion was found to be concentrated along the banks of major rivers and at the land-water interface of the Bay of Bengal [4].

Using Landsat TM and Landsat ETM+ images (Figure 4A-C), changes in the extreme northern part of Chandpai and Khulna Ranges from 1989 to 2000 and 2010 have been studied [29]. There were several natural calamities during the study period: (i) severe flood covering over $60 \%$ of the country and a cyclone in 1988; (ii) cyclone in 1991; (iii) flood covering $75 \%$ of the country in 1998; (iv) Cyclones Sidr in 2007 and Aila in 2009. A large number of small rivers and creeks were formed sometime before the year 2000 (Figure 4C). One possibility for the changes is that the high discharge of 7020 and $8880 \mathrm{~m}^{3} \cdot \mathrm{s}^{-1}$ at Gorai in 1991 and 1993, respectively (Figure 2), following tidal surge of the cyclone in April 1991, forced the huge water-mass to pass across the wetlands forming creeks and small rivers. The forest margins also eroded, increasing the water area (Table 1) by $18.07 \%$ in 2000 and again by $7.67 \%$ in 2010 , a total increase of $27.12 \%$ [29]. There was no change in small rivers and creeks after 2000 though there were Cyclones Sidr in 2007 and Aila in 2009 (Figure 4C). The eroded soil formed new marshy areas of $5.85 \mathrm{~km}^{2}$ (3.87 km² by the year 2000 and again $1.98 \mathrm{~km}^{2}$ by 2010). The photographs in The Bangladesh Sundarbans represent some of these changes [1]: a small creek on page 24 with a number of fallen trees along the banks; sediment deposition on riversides on pages 23 and 36 . The forest area of $443 \mathrm{~km}^{2}$ was 
reduced to $427 \mathrm{~km}^{2}$, a total loss of $16 \mathrm{~km}^{2}$ which is $3.61 \%$ over 20 years (Table 1) [29]. If the percentage of small rivers and creek formation are considered for other parts of the BSMF in addition to large rivers, and assuming that the area plus higher erosion near the coast constitute about $33 \%$ (about $2000 \mathrm{~km}^{2}$ ), then the estimated total forestland loss would be about $127 \mathrm{~km}^{2}$.

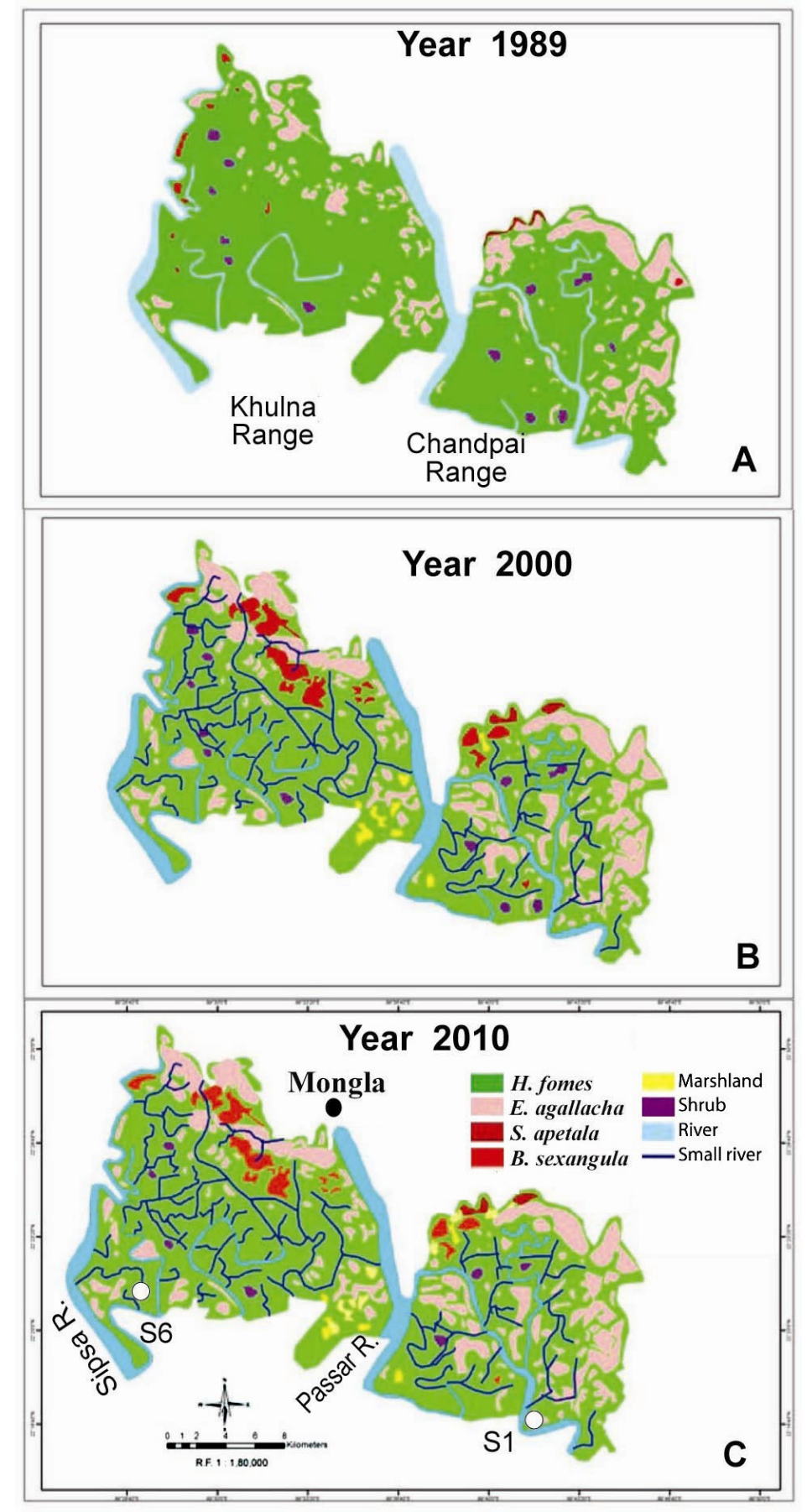

Figure 4. Landsat $\mathrm{TM}$ and Landsat $\mathrm{ETM}^{+}$images, showing changes in species composition of parts of forests of Khulna and Chandpai Ranges in 1989 (A), 2000 (B) and 2010 (C) of BSMF [29]. Detail data of the images is given in Table 1. 
Table 1. Changes (in ha) of forest cover, marsh and water area from 1989 to 2000 and 2010, determined by GIS technique at Khulna and Chandpai ranges (one spot from each and together). Values within parentheses is percent [29].

\begin{tabular}{ccccccc}
\hline Classes & \multicolumn{3}{c}{ Plant Cover and Water Area } & \multicolumn{3}{c}{ Changes } \\
\hline & $\mathbf{1 9 8 9}$ & $\mathbf{2 0 0 0}$ & $\mathbf{2 0 1 0}$ & $\mathbf{1 9 8 9 - 2 0 0 0}$ & $\mathbf{2 0 0 0 - 2 0 1 0}$ & Overall \\
\hline Heritiera fomes & 23,028 & 19,309 & 16,408 & $-3719(16.15)$ & $-2901(15.02)$ & $-6620(28.75)$ \\
Excoecaria agallocha & 15,184 & 15,828 & 16,200 & $+644(4.24)$ & $+372(02.35)$ & $+1016(6.7)$ \\
Sonneratia apetala & 44 & 1906 & 109 & $+1862(4231)$ & $-1797(94.28)$ & $+65(148)$ \\
Bruguiera sexangula & 191 & 8169 & 3026 & $+7978(4177)$ & $-5143(63)$ & $+2835(1484)$ \\
Marshes & - & 387 & 585 & $+387(100)$ & $+198(33.85)$ & $+585(100)$ \\
Shrubs & 570 & 463 & 367 & $-107(18.77)$ & $-96(20.73)$ & $-203(35.61)$ \\
Water & 4727 & 5581 & 6009 & $+854(18.07)$ & $+428(7.67)$ & $+1282(27.12)$ \\
Total area & 44,301 & 44,328 & 42,704 & $+27(0.06)$ & $-1624(3.66)$ & $-1598(3.60)$ \\
\hline
\end{tabular}

Changes over 40 years of the total Sundarbans from the 1970s to 2000s have been studied using Landsat satellite data [4]. From the $1970 \mathrm{~s}$ to $1990 \mathrm{~s}$, forestland increased by $1.4 \%$, but from the $1990 \mathrm{~s}$ to $2000 \mathrm{~s}$, the area decreased by $2.5 \%$ and the net loss was $1.1 \%$. The loss equals $110 \mathrm{~km}^{2}$ for the total Sundarbans and about $66 \mathrm{~km}^{2}$ for the Bangladesh Sundarbans. However, the BSMF is likely to incur more loss due to a cyclone in 1991 and a severe flood in 1998. Of the total loss, approximately 50\% was lost at the Bay of Bengal (the extreme southern edge of the BSMF where almost no compensating aggradation took place) [4]. Within the same tenure, the water bodies in the BSMF have been reported to increase by nearly $30 \mathrm{~km}^{2}$ [30] which, in other words, means a decrease in forestland. The decrease of sediment-laden water from the Ganges every year results in the further erosion of forestland. The situation will be further aggravated by global warming in the future. If reclamation of the BSMF is not initiated immediately, it may be that after about 100 years or so, the BSMF will be washed away into the Bay of Bengal [20]. Predictions suggest that $100 \%$ of the mangrove forests could be lost in the next 100 years if the present rate of loss continues [11].

\section{Floral Diversity}

Vegetation of the BSMF: A total of 70 species from 34 families of the entire Sundarbans has been reported [31]. From the Bangladesh Sundarbans, 65 species (large trees 10, small trees 20, shrubs 25 and herbs 10 including two ferns) of 37 families have been reported [32] (Table 2). Recently, a total of 115 species have been recorded, where, in addition to more than 10 large trees, seven more (Avicennia marina, Bruguiera parviflora, B. sexangula, Ceriops candellana, C. roxburghiana, C. tagal, Rhizophora apiculata) are added including 10 species of sedges, five species of grasses, and many species from other groups [3]. The listed plants need a thorough check to identify true mangroves. However, if the seven tree species are found to be correctly identified, the number of true mangrove trees would be 17 . The Indian part of the Sundarbans has 34 true and 12 obligate (epiphytic and other plants occurring also outside the Sundarbans) mangroves [16]. In the BSMF, eight dominant plants were recognized to form forest categories: Heritiera fomes, Excoecaria agalocha, Xylocarpus mekongensis, X. granatum, Bruguiera gymnorhiza, Sonneratia apetala, Avicennia officinalis and Ceriops decundra [14]. 
Table 2. Flora of the Bangladesh Sundarbans [14].

\begin{tabular}{|c|c|c|c|}
\hline Scientific Name & Family & Vernacular Name & Type of Plant \\
\hline Acanthus ilicifolius & Acanthaceae & Hargoza & Scrambling herb \\
\hline Acrostichum aureum & Pteridiaceae & Hodo, tiger fern & Gregarious fern \\
\hline Aegialitis rotundifolia & Plumbaginaceae & Dhalchaka & Small tree \\
\hline Aegiceras coriculatum & Myrsinaceae & Khalisha, Khalshi & Shrub or small tree \\
\hline Amoora cucullata & Meliaceae & Amur & Small tree \\
\hline Avicennia alba and/or & Avicenniaceae & Sada baen & Small tree \\
\hline A. marina & Avicenniaceae & Morcha baen & Small tree \\
\hline Avicennia officinalis & Avicenniaceae & Baen & Tree \\
\hline Barringtonia racemosa & Barringtoniaceae & Kumba, Kumbi & Small tree \\
\hline Blumea amplectens & Compositae & Hash & Aromatic herb \\
\hline Brownlowia tersa & Tiliaceae & Ota sundri & Climbing shrub \\
\hline Bruguiera gymnorrhiza & Rhizophoraceae & Kankra & Tree \\
\hline Caesalpinia crista & Leguminosae & Kutum katta & Climbing armed shrub \\
\hline Cerbera manghas & Apocynaceae & Dagor & Small tree \\
\hline Ceriops decandra & Rhizophoraceae & Goran & Shrub or small tree \\
\hline Clerodendrum inerme & Verbenaceae & Sitka, Sitki & Climbing shrub \\
\hline Cynometra ramiflora & Leguminosae & Shingra & Shrub \\
\hline Cyperus javanicus & Cyperaceae & Kucha, Kusha & Sedge \\
\hline Dalbergia candenatensish & Leguminosae & Chanda lota & Scrambling climber \\
\hline D. spinosa & Leguminosae & Chanda katta & Climbing armed shrub \\
\hline Dendrophthoe falcate & Loranthaceae & Porgassa & Woody parasite on trees \\
\hline Derris trifoliate & Leguminosae & Gila lota, kali lota & Climber \\
\hline Diospyros peregrine & Ebenaceae & Gaeb & Tree \\
\hline Drypetes sp. & Euphorbiaceae & Achet & Climbing shrub \\
\hline Eriochloa procera & Gramineae & Nol hash & Grass \\
\hline Eugenia fruticosa & Myrtaceae & Ban jam, Jam gach & Small tree \\
\hline Excoecaria agallocha & Euphorbiaceae & Gewa & Tree \\
\hline E. indica & Euphorbiaceae & Batla, Batul & Small tree \\
\hline Ficus retusa & Moraceae & Jir & Tree with aerial roots \\
\hline Flagellaria indica & Flagellariaceae & Abetaa & Climber \\
\hline Flueggia virosa & Euphorbiaceae & Sitka, Sitki & Climbing shrub \\
\hline Heritiera fomes & Sterculiaceae & Sundri & Tree \\
\hline Hibiscus tiliaceous & Malvaceae & Bhola & Shrub \\
\hline Hoya parasitica & Asclepiadaceae & Agusha & Climber \\
\hline Imperata cylindrical & Gramineae & & Grass \\
\hline Intsia bijuga & Leguminosae & Bhaela, Bharal & Small tree \\
\hline Ipomoea pes-caprae & Convulvulaceae & Gash & Succulent herb \\
\hline Ixora sp. & Rubiaceae & Bon bakul & Small tree \\
\hline Kandelia candel & Rhizophoraceae & Gura, Gural & Small tree \\
\hline Leea aequata & Leeaceae & & Shrub \\
\hline Lepisanthes rubiginosa & Sapindaceae & Bon lichu & Tree \\
\hline Lumnitzera racemosa & Combretaceae & Kirpa, Kripa & Small tree \\
\hline Macrosolen cochinchinensis & Loranthaceae & Porgassa & Woody parasite \\
\hline Mallotus repandus & Euphorbiaceae & Bon notoy & Climbing shrub \\
\hline Macuna gigantean & Leguminosae & Doyal & Climber \\
\hline
\end{tabular}


Table 2. Cont.

\begin{tabular}{lccc}
\hline \multicolumn{1}{c}{ Scientific Name } & Family & Vernacular Name & Type of Plant \\
\hline Myriostachya wightiana & Gramineae & Dhanshi & Grass, on accretions \\
Nypa fruticans & Palmae & Golpata & Palm, underground stem \\
Pandanus foetidus & Pandanaceae & Kewa katta & Prickly screw-pine \\
Petunga roxburghii & Rubiaceae & Narikili & Small tree \\
Phoenix paludosa & Palmae & Hantal & Thorn palm \\
Phragmites karka & Gramineae & Nol khagra & Grass \\
Pongamia pinnata & Leguminosae & Karanja & Small tree \\
Premna corymbosa & Verbenaceae & Serpoli, Setpoli & Shrub or small tree \\
Rhizophora mucronata & Rhizophoraceae & Garjan, Jhanna & Tree with stilt roots \\
Salacia chinensis & Celastraceae & Choyt barai & Small tree \\
Sarcolobus globosus & Asclcpiadaccae & Bowali lota & Climber \\
Sonneratia apetala & Sonneratiaceae & Keora & Tree \\
S. caseolaris & Sonneratiaceae & Choyla & Small tree \\
Stenochlaena palustris & Blechnaceae & Dekilota & Climbing fern \\
Tamarix indica & Tamaricaceae & Jhao, Nona jhao & Small tree \\
Tetrastigma bracteolatum & Vitidiaceae & Golgoti lota & Climber \\
Thunbergia sp. & Thunbergiaceae & Jermani lota & Climber \\
Viscum monoicum & Loranthaceae & Shamulota & Woody parasite on trees \\
Xylocarpus granatum & Meliaceae & Dhundul & Small tree \\
X. mekongensis & Meliaceae & Passur & Tree \\
\hline
\end{tabular}

Phytoplankton: Phytoplankton communities consist of a total of 35 taxa (Table 3) [25]; including nano- and picoplankton, the number exceeds 50. Oocystis pussilla, a freshwater phytoplankton, was recorded as dominant under all salinity conditions. The presence of a good number of Pennales members and some other freshwater species indicates a strong influence of freshwater in the BSMF or that they have adapted to varying salinity. Phytoplankton are found to be small in number, only two to 12 individuals or cells per liter. Diatoms were found to show positive correlation with conductivity, TDS, salinity and alkalinity.

Benthic algae: A total of 35 benthic algae have been recorded [33] (Table 3). Most spectacular are species of Catenella, Caloglossa, Bostrychia and Cladophorella growing on pneumatophores and on stems submerged during high tide; Enteromorpha intestinalis as a drifted form, while others grow on muddy forest floor. Colpomenia sinuosa, though small in size, was found growing on the margin of inundated forestland. 
Table 3. Phytoplankton [25] and benthic [33] algal flora of the BSMF.

\begin{tabular}{|c|c|}
\hline Phytoplankton & Benthic Algae \\
\hline Chlorophyceae & Cyanophyceae \\
\hline 1. Oocystis pusilla & 1. Aphanothece castagnei \\
\hline 2. Staurastrum orbiculare & 2. Oscillatoria amoena \\
\hline 3. Uronema sp. & 3. Oscillatoria subbrevis fa. major \\
\hline Euglenophyceae & 4. O. tenuis \\
\hline 4. Astasia cylindrica & 5. Lyngbya confervoides \\
\hline 5. Euglena spathirhyncha & 6. L. lutea \\
\hline Bacillariophyceae: Centrales & 7. Hydrocoleum cantharidosum \\
\hline 6. Bacteriastrum delicatulum & 8. Anabaena variabilis \\
\hline 7. Biddulphia dubia & 9. Scytomena siculum \\
\hline 8. Chaetoceros pendulus & Rhodophyceae \\
\hline 9. C. socialis & 10. Catenella nipae \\
\hline 10. Chaetoceros sp. & 11. C. repens \\
\hline 11. Coscinodiscus excentricus & 12. Caloglossa adnata \\
\hline 12. C. granii & 13. C. leprieurii \\
\hline 13. C. jonesianus & 14. Pterosiphonia pennata \\
\hline 14. C. lineatus & 15. Bostrychia radicans \\
\hline 15. C. marginatus & 16. B. tenella \\
\hline 16. C. oculus-iridis var. boreales & Chlorophyceae \\
\hline 17. Cyclotella comta & 17. Entermorpha intestinalis \\
\hline 18. Rhyzosolenia setigera & 18. E. prolifera \\
\hline 19. Skeletonema costatum & 19. Ulva lactuca \\
\hline 20. Thalassiosira weissflogii & 20. Rhizoclonium grande \\
\hline 21. T. rotula & 21. R. hookeri \\
\hline Bacillariophyceae: Pennales & 22. R. kerneri \\
\hline 22. Amphiprora alata & 23. $R$. riparium \\
\hline 23. Amphora ovalis & 24. Lola capillaris \\
\hline 24. A. veneta & 25. L. implexa \\
\hline 25. Navicula brekkaensis & 26. L. tortuosa \\
\hline 26. Nitzschia acicularis & 27. Chaetomorpha aerea \\
\hline 27. N. closterium & 28. C. gracilis \\
\hline 28. $N$. inconspicua & 29. Cladophorella sundarbanensis \\
\hline 29. N. rotnada & 30. Boodleopsis sundarbanensis \\
\hline 30. N. sigma & Xanthophyceae \\
\hline 31. Nitzschia sp. & 31. Vaucheria erythrospora \\
\hline 32. Surirella fastuosa var. recedens & 32. $V$. prescotti \\
\hline 33. Thalassionema nitzschioides & 33. $V$. pronosperma \\
\hline 34. Lioloma delicatula & 34. V. mayyanadensis \\
\hline Xanthophyceae & Phaeophyceae \\
\hline 35. Centritractus belanophorus & 35. Colpomenia sinuosa \\
\hline
\end{tabular}

Effect of salinity on vegetation, plant distribution and density: There is a range of tolerance of mangrove trees to salinity, among which the single most important species of the BSMF is the Heritiera fomes. A comparison of the forest types observed after nine years of the operation of Farakka Barrage 
revealed $10.4 \%$ decreased area coverage of $H$. fomes and a decrease of total tree cover of $4 \%$ (Table 4 .). The data show that there is a change in favor of mixed Heritiera fomes and Excoecaria agalocha forest at the expense of pure $H$. fomes forest. The area of E. agalocha to $H$. fomes forest has remained almost constant where E. agalocha is more tolerant to salinity. A very recent study also showed that the Heritiera fomes is very sensitive to at or above $1.0 \%$ salinity while E. agalocha appears to be more tolerant to moderate levels of salinity and Ceriops decundra is the most salt-loving plant [29]. A comprehensive inventory of Sundarbans based on aerial photography revealed $99 \%$ of the total area of the forests was accounted for by 10 forest types: pure H. fomes, H.fomes-E. agallocha, H. fomes-other spp., E. agallocha-H. fomes, pure E. agallocha, E. agallocha-C. decandra, C. decandra-E. agallocha, pure $C$. decandra, pure $S$. apetala and other minor spp. [34]. Department of Forests, Bangladesh showed 17 forest types (Figure 1C). A total of 47 taxa were recorded from three saline zones of the BSMF of which 30 taxa were found in oligohaline, 21 in mesohaline and 13 in polyhaline zones [35]. All the plant species are indigenous and so far none is considered as rare [5]. Tree density has been summarized as $43.2 \%, 37.2 \%$ and $13.6 \%$ in oligohaline, mesohaline and polyhaline zones, respectively [23].

Table 4. Changes of forest types in the BSMF in 1959 [34] and 1983 [14].

\begin{tabular}{lcc}
\hline \multirow{2}{*}{ Forest Types } & \multicolumn{2}{c}{ Area Occupied (\%) } \\
\cline { 2 - 3 } & $\mathbf{1 9 5 9}$ & $\mathbf{1 9 8 3}$ \\
\hline Heritiera fomes & 31.6 & 21.0 \\
H. fomes-Excoecaria agallocha & 24.4 & 29.7 \\
E. agalocha-H. Fomes & 15.6 & 14.8 \\
Total & 71.5 & 65.5 \\
\hline
\end{tabular}

Landsat TM, Landsat $\mathrm{ETM}^{+}$images and GIS data on the changes of forest cover from 1989 to 2000 and 2010 at the extreme northern part of Khulna and Chandpai Ranges revealed a decreased total tree cover of 3.61\%; decreased Heritiera fomes of $28.75 \%$, but increased salt-loving Bruguiera sexangula, Excoecaria agallocha and Sonneratia apetala (Figure 4, Table 1) [29]. The result coincided well with the findings of others [14]. B. sexangula showed a several hundred percent increase over 20 years from 1989. There was a gradual decrease of shrubs of $35.61 \%$.

Increase in salinity affected growing stock of the mangroves. A total of 296 growing stock per ha in 1959 [34] was reduced to 180 by 1983 [14] and 144 (48.65\%) by 1996 recorded by Bangladesh Forest Department in the BSMF (Table 5). Trend analysis (using “Table Curve 2D" program) showed that by 2020, the total number of plants will be reduced to $109(36.82 \%)$ and the number of $H$. fomes will be reduced to 80 per ha (37.9\% compared to 1959) [34]. Salinity increase also affects growth of Nypa fruticans (golpata).

Table 5. Inventories * and Trends ** (estimated using "Table Curve 2D" Program) of BSMF growing stocks (no. per ha).

\begin{tabular}{ccccc}
\hline Sl. No. & Inventory/Trend & H. Fomes $(\mathbf{d b h} \geq \mathbf{1 5} \mathbf{~ c m})$ & $\boldsymbol{E}$. Agallocha & Total Trees \\
\hline 1. & $1959[34]^{*}$ & 211 & 61 & 296 \\
2. & $1983[14]^{*}$ & 125 & 35 & 180 \\
3. & $1996^{*}$ & 106 & 20 & 144 \\
4. & In $2020^{* *}$ & 80 & 7 & 109 \\
\hline
\end{tabular}


Effect of salinity on plant height and canopy cover: Salinity results stunted growth of trees, creating scrubby forests. A comparison of height class in 1959 [34] with 1983 [14], after 25 years or about 10 years of Farakka Barrage operation, revealed that the height class 1 (plant height is $\geq 15 \mathrm{~m}$ ) in the northeast has fragmented into height class 2 (plant height 10 to $<15 \mathrm{~m}$ ) and height class 2 into height class 3 (plant height 3 to $<10 \mathrm{~m}$ ). Diameter of stems at breast height is also affected. Annual increase of diameter for Heritiera fomes was found to be $0.133 \mathrm{~cm} /$ year in the oligohaline zone, while in the meso- and polyhaline zones, the increases were 0.102 and $0.062 \mathrm{~cm} /$ year, respectively [23]. The gradual darkness of the forests towards the east in the satellite image (Figure 1) indicates dominance of dense, tall trees towards the eastern part. There was a decrease in canopy closure of BSMF, where the $78 \%$ of forestland that had a canopy closure of $75 \%$ or more in 1959 [34] was found to decrease to $65 \%$ in 1983 [14] and to about nil in 1996 [28]. The effects of salinity on the tree height and canopy closure have been summarized as: tree height of 15 to 20,10 to 15 and 3 to $5 \mathrm{~m}$ in oligohaline, mesohaline and polyhaline zones, respectively, and canopy closure of $60 \%$ to $100 \%, 40 \%$ to $80 \%$ and $30 \%$ to $70 \%$ in oligohaline, mesohaline and polyhaline zones, respectively [23].

Effect of salinity on plant growth: Seedling survivability of Heritiera fomes after 33 months of their appearance in the forests of three zones showed survivability rates of $16.53 \%, 1.93 \%$ and $0.00 \%$ in oligo-, meso- and polyhaline zones, respectively. A similar trend was found for other mangroves except Excoecaria agalocha $(0.391 \%$ in oligo- and $14 \%$ in polyhaline conditions) [23]. It appears that plants of BSMF in general are more adapted to low salinity.

The incidence of Heritiera fomes top-dying and increase in soil salinity in the affected sites indicate a strong relationship and suggest that increase in salinity is possibly the predominant factor in the onset of the condition. Soil $\mathrm{pH}$ around 6.5 is generally ideal for $\mathrm{PO}_{4}-\mathrm{P}$ absorption. The sundri plant is probably best suited at or just above this $\mathrm{pH}$, above which it showed pathological symptoms like top dying. Subsequently, bacteria and saprophytes invade. It is concluded that much of the Sundarbans no longer provides an environment to which $H$. fomes is ecologically well suited [14].

\section{Faunal Diversity}

The BSMF harbors a good number of faunal species but the number and population density vary in available reports. According to a recent report, there are 1136 species of wildlife which include 315 species of birds (including 84 migratory), 289 terrestrial species of which 49 species are mammals, one of which is the great royal Bengal tiger (the number is estimated to be 440) and 678 aquatic species (of which 210 are fish species), including 59 reptiles, eight amphibians, 11 cetaceans and 16 mollusks which constitute about $35 \%$ of the total fauna of Bangladesh [3]. Important mammal species include the spotted deer, barking deer, macaque monkey, wild boar, jackal, Indian fishing cat, civets, small mongoose, common otter, smooth coated otter, bats, Irrawady squirrel, crestless Malayan porcupine, large bandicoot rat, etc. Principal reptile species are marsh/estuarine crocodile, python, common cobra, gecko, sea snakes, monitor lizard, turtles, etc. The aquatic birds include storks, herons, egrets, adjutants, little cormorant, etc. Semi-aquatic birds are plovers, red-wattled lapwing, avocet, stint, curlew, sandpiper, common greenshank, gulls, terns, etc. The SMF waters harbors Ganges River dolphins, Irrawady dolphins, Indo-Pacific humpback dolphins and finless porpoises. Several raptorial birds include the eagles, falcons, vultures, kites, harriers, etc. Some terrestrial birds are doves, kingfishers, woodpeckers, 
pigeons, flycatchers oriental magpie robin, red jungle fowls, owls, rose-winged parakeet, etc. The rich avifauna of the BSMF and surroundings constitute about $48 \%$ (of which about $15 \%$ are migratory) of the total avifauna of Bangladesh. Of about 210 fish species, 120 species of fish are commonly caught from the BSMF. There are eight commercially important species of finfish, shrimp and crabs, and at least 11 species of bivalves in estuarine areas.

\section{Resources of the Bangladesh Sundarbans}

The resources in the BSMF is limited to a group of commercially important plants (out of 65 plant species recorded (Table 2), which are Heritiera fomes, Excoecaria agalocha, Ceriops decandra, Sonneratia apetala, Xylocarpus mekopngensis, Bruguiera sexangula, Avicennia officinalis, Tamarix indica, Aegiceras corniculata and Nypa fruticans, and a few others including, Amoora cuculata, Rhizophora mucronata and Cynometra ramiflora [14]. The H. fomes is over $50 \mathrm{~m}$ tall and is the highest carbon-storing plant in the BSMF. The BSMF was overexploited up until 1988 after which its exploitation has been totally stopped.

Value of the mangroves systems: At present, the total carbon in the BSMF measured in 2010 by the Forest Department, GoB, is about 56 million metric tons (pers. comm. M.A. Motaleb, Ex Chief Conservator of Forests, Dhaka). Carbon trading is a market mechanism intended to tackle global warming by giving the $\mathrm{CO}_{2}$-emitting countries the chance to cover the costs of cutting emissions or continuing emissions and paying someone else to cut this pollution. Bangladesh is a signatory of the Copenhagen Accord, UN Framework Convention on Climate Change and can sell the BSMF carbon at US\$ 5 to 15 per ton (US\$ 25 in Finland) which is about US\$ 280 to 840 million per year. If environmental degradation due to freshwater scarcity would not occur, the carbon reserve in the BSMF now could be about 112 million tons, amounting to US\$ 0.56 to 1.68 billion per year. In terms of the value of the ecosystem services including storm and coastal protection, the Bangladesh Sundarbans generate ecosystem services valued at between US\$ 273 and 714 million per year [36]. From 2005 to 2010, the global carbon trading market had only US\$ 142 billion and Bangladesh could not sell yet. Carbon-emitting countries should initiate savings and reclaim the Bangladesh Sundarbans as a matter of priority.

Harvesting of $H$. fomes, Sonneratia apetala, etc. is strictly prohibited. E. agallocha and Ceriops dacandra cuttings have been allowed only on a limited scale since January 2009 for rehabilitation of forest-dependent populations after Cyclone Aila hit in 2009. The fish catch in the BSMF is high, though concentration of phytoplankton and epiphytic algal growth is relatively low because of highly turbid tidal waters [25]. The decomposed plant parts are feed for detrivorous fishes. On average, about 10 metric tons of fish are harvested every day, in addition to a collection of crabs and mollusks. The total revenue ranges between US\$717,409 and 879,181 in recent years (Table 6). 
Table 6. Forest products and revenue (in BDT) obtained during 2008 to 2009 and 2012 to 13 from the BSMF.

\begin{tabular}{|c|c|c|c|c|c|}
\hline \multirow{2}{*}{ Sl. No. } & \multirow{2}{*}{$\begin{array}{c}\text { Type of Forest } \\
\text { Produces (Unit) }\end{array}$} & \multicolumn{2}{|c|}{ 2008-2009 } & \multicolumn{2}{|c|}{ 2012-2013 } \\
\hline & & Amount & Revenue & Amount & Revenue \\
\hline 1. & $\begin{array}{c}\text { Excoecaria agallocha }\left(\mathrm{m}^{-3}\right) \\
*\end{array}$ & 613 & 779,626 & 252 & $1,254,319$ \\
\hline 2. & Ceriops decandra (no.) $*$ & 88,708 & 363,628 & 66578 & 379,290 \\
\hline 3. & Nypa fruticans (ton) & 37,534 & $4,620,713$ & $31,761.6$ & $8,275,050$ \\
\hline 4. & Fishes (ton) & 4524.5 & $21,331,210$ & 3484.5 & $13,569,648$ \\
\hline 5. & Grass (ton) & 493 & 10,853 & 1101 & 29,837 \\
\hline 6. & Phoenix paludosa (ton) & 60 & 42,846 & 73.02 & 105,899 \\
\hline 7. & Honey (ton) & 110 & 608,520 & 233 & $1,747,422$ \\
\hline 8. & Mollusk Shell (ton) & 1349 & 40,987 & 182.714 & 32,888 \\
\hline 9. & Wax (ton) & 22.81 & 228,195 & 58.93 & 589,315 \\
\hline 10. & Crab (ton) & 1318.5 & $3,743,765$ & 1253.80 & $4,901,712$ \\
\hline 11. & Tourists (No.) & 183,600 & $4,419,960$ & 150,037 & $19,873,725$ \\
\hline 12. & Wood $\left(\mathrm{m}^{-3}\right) * *$ & 522.60 & $8,452,509$ & 293 & $2,220,170$ \\
\hline 13. & Fuel $\operatorname{wood}\left(\mathrm{m}^{-3}\right) * *$ & 850 & 557,209 & 453 & $8,39,173$ \\
\hline 14. & Miscellaneous & - & $10,040,444$ & - & $13,878,556$ \\
\hline & Total & & $\begin{array}{c}48,202,163 \\
\mathrm{US} \$=717,409\end{array}$ & - & $\begin{array}{c}67,697,004 \\
\mathrm{US} \$=879,181\end{array}$ \\
\hline
\end{tabular}

The increased revenue of some items in 2012 to 2013 were due to imposition of increases in price. * Cuttings are allowed only at a very limited scale after the Cyclone Aila in 2009. ** Confiscated (unauthorized).

\section{Threats to the Systems}

Natural disasters and man made factors: Cyclonic storms and tidal surges severely affect the biotic communities of the coast by uprooting plants, eroding coastal soils, breaking stems and branches, human settlements and lives. During the 1988 cyclone, a total of 3,713,655 Heritiera fomes and 4,718,420 Sonneretia apetala were damaged [3]. Some other natural disasters that affected the SMF include: flood and tidal surge in 1985, flood in 1987, cyclone in 1991, flood covering 75\% of Bangladesh in 1998, floods in 2004 and 2007, cyclone Sidr in 2007, Cyclone Aila in 2009, cyclone Mahashen in 2013 destroying a large number of mangroves, and human settlements at the impact zone. Manmade factors for the degradation of BSMF include diversion of freshwater from the Ganges at Farakka, navigation, oil pollution, construction of coal-fired power plants, industrial pollutants, heavy metals, shrimp cultivation, pesticides, poaching and lack of execution of laws. The pollutants accumulated during dry periods are washed and carried to the Bay of Bengal during monsoon. It is assumed that the accumulated pollutants will have legacy effect years into the future.

Oil pollution: Mongla International Shipping Port has a harboring capacity of over 70 oceangoing ships at a time. Thus, effects of navigation and the possibility of oil slick to a certain extent is there, and authorities have taken measures (imposing fines) to reduce the chance of oil spills. Oil spills will affect many of the ecological systems. Amongst fungal populations, species of Aspergillus (75\%) and Helminthosporium (about 25\%) are involved in the process of decomposition [16]. A tanker containing 350,000 liters of heavy furnace oil sunk in River Shella north of Chandpai Range, Sundarbans on 9 
December 2014, and by about $30 \mathrm{~h}$, the thick carpet of oil spread at least $20 \mathrm{~km}$ up (including Mongla Port) and down stream. Chemical spray was not allowed, but 70,000 liters of oil was collected manually. The massive collection of oil through the joint effort of the community and Department of Forest reduced the intensive impact on livelihood as concluded in the Sundarbans Oil Spill Assessment, jointly conducted by the United Nations and the Government of Bangladesh Mission [37].

Coal-fired power plant: The under construction plant at Rampal, about $14 \mathrm{~km}$ north of the BSMF, has planned to produce 1320 megawatts of electricity, and will require 13,000 metric tons of coal per day, releasing about 8 million tons of $\mathrm{CO}_{2}, 0.75$ million tons of fly ash and 0.2 million tons of bottom ash annually. Moreover, $5000 \mathrm{~m}^{3}$ hot water per $\mathrm{h}$ will be released into the river that leads to Passur River and to the BSMF river system. The coal-fired power plant will be the largest threat to the Sundarbans. The project should be abandoned for the sake of the Bangladesh Sundarbans.

Threats to carbon deposits: The growing stock (number of trees per ha) of the BSMF was reduced to less than $50 \%$ by the year 2000 (Table 5). At this stage, the total carbon deposit was estimated to be 56 million metric tons. By the year 2020, the carbon deposit will come down to about $33 \%$ if the present situation prevails.

Threats to plant communities: Heritiera fomes is considered threatened due to salinity increases, top dying and illegal felling while Nypa fruticans is being threatened by gradual increases in salinity [28]. Out of Bruguiera parviflora, B. racimosa, B. gymnorrhiza and B. sexangula recorded [31] only B. racimosa is not found in BSMF [3] nor in the Indian part [16]. Lumnitzera racimosa is very limited in distribution. Amoora cuculata, Rhizophora mucronata and Cynometra ramiflora are threatened due to unregulated felling [38].

Threats to animal communities: Historical records suggest the loss of at least six mammal species in recent times; those are Rhinoceros sondaicus, Rhinoceros unicornis, Bulbulus bulbulus, Bos gaurus, Cervus duvaucali and Axis porcinus. The marsh crocodiles (Crocodylus porosus), once abundant, are now quite rare and the rock python (Python morulus) is listed as vulnerable by International Union for Conservation of Nature [3]. A total of over 40 species of Amphibia, Reptilia, Aves and Mammalia are listed either as critically endangered, endangered or vulnerable [39].

\section{Conservation}

The BSMF has been under scientific management for more than 100 years. It is being maintained by four ranges such as, Sarankhola to the east, followed to the west by Chandpai, Khulna and Satkhira; the last range separates the Indian part of the Sundarbans by Harinbhanga River. The whole BSMF has a total of 55 compartments and is under the control of Sundarbans Forest Circle.

The BSMF possesses huge wetlands of international importance and was declared as a Ramsar site in the year 1992. The Sundarbans were declared as Sundarban Reserve Forests in 1876 and as a Natural World Heritage Site by the UNESCO in 1997 to conserve all its unique flora and fauna. Given its rich biodiversity and the unique ecosystem that lies within the forest, the ecological and environmental importance of the forest is immense [1].

Sundarbans Impact Zone: A 15 to $20 \mathrm{~km}$ band to the north and east of the BSMF has been considered as an Ecologically Critical Area (Sundarbans Impact Zone) since 1999 under the Bangladesh Environment Conservation Act 1995. The act is dedicated to the protection and maintenance of 
biological diversity to achieve the long-term conservation of nature with associated ecosystem services and cultural value. The zone is surrounded by agricultural lands and human settlements and consists of 154 Unions and 17 Upazilas of Khulna, Satkhira, Bagerhat, Pirojpur and Borguna districts having an estimated population of 3.5 million. They are also dependent on BSMF for fishing, harvesting honey, Nypa leaves, etc. A commercial logging ban is in place until 2015. There is no human encroachment in the BSMF.

Sanctuaries: There are three wildlife sanctuaries facing the Bay of Bengal: the Sundarbans East established in 1960, Sundarbans South and Sundarbans West established in 1977 (Figure 1C). Total area of the sanctuaries is $1397 \mathrm{~km}^{2}$. UNESCO declared these sanctuaries and the Sundarbans as Natural World Heritage Sites in 1997 [1,3].

Restricted fishing areas: There are over 210 species of fish in the BSMF, and 120 species are harvested. They are also used as feed for other aquatic animals. For conserving them, Bangladesh Forest Department identified 18 small rivers in all four ranges. In addition, measures for selective fishing and protection of brood areas have been undertaken $[1,3]$.

National Forest Policy: Environmental policy for conservation and protection of forest resources including coastal and marine areas, through Ministry of Environment and Forests, GOB has been incorporated. To reduce global warming, "Reduced Emission from Deforestation and forest Degradation" (REDD ${ }^{+}$) as per the Copenhagen Accord, has been implemented. The principle of REDD ${ }^{+}$ is that the plants in the BSMF will be allowed to grow for an indefinite period, die and decompose naturally, slowing down the release of greenhouse gases. Compensation will be accrued from developed countries. However, to achieve the REDD ${ }^{+}$goal, the salinity intrusion in the BSMF must be stopped, and measures be taken to reclaim the Bangladesh Sundarbans to secure a Class 1 forest type as proposed through reclamation of the Sundarbans [20].

Sundarbans, a natural wall: Recently, many of the cyclones that were supposed to strike Sundarbans changed their routes towards Chittagong, a phenomenon that is most likely due to buffering of the atmosphere around the Sundarban Mangrove Forests and other coastal forests, securing Bangladesh (Figure 5). The BSMF is also acting against global warming by storing over 56 million metric tons of carbon.
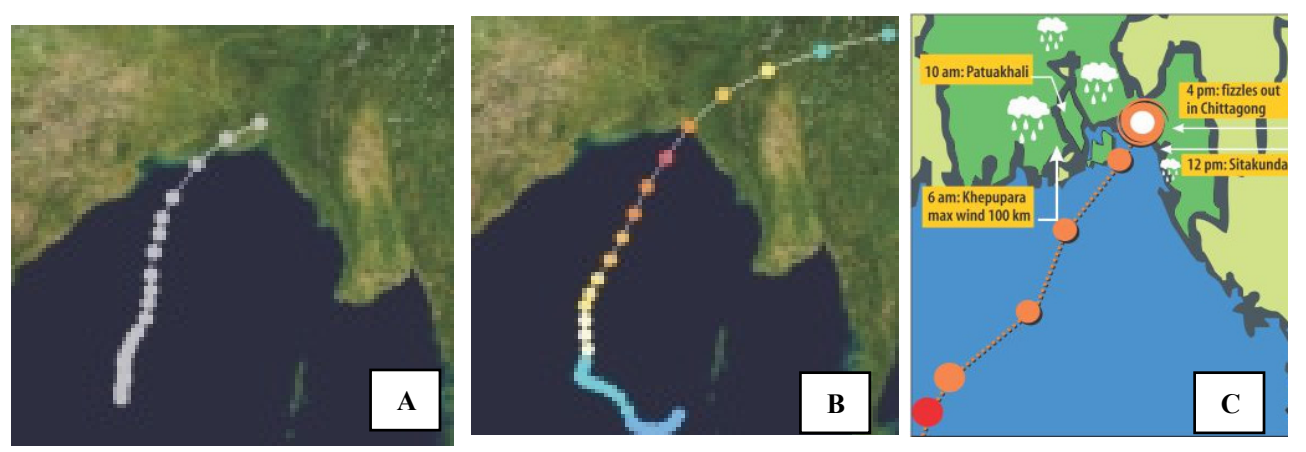

Figure 5. The routes of cyclones in the Bay of Bengal and landfall in Bangladesh: (A) 11 November 1970, wind speed $205 \mathrm{~km} / \mathrm{h}$ at Bhola; (B) 29 April 1991, wind speed $260 \mathrm{~km} / \mathrm{h}$ at Chittagong and (C) 16 May 2013, wind speed $100 \mathrm{~km} / \mathrm{h}$ "Mahasen" at Chittagong, Bangladesh. Source: The Daily Star newspaper. 


\section{Reclamation of the BSMF}

Sundarbans Mangrove Forests are the largest contiguous tract of mangroves in the world, formed about 7000 years ago by the deposition of sediments from the foothills of the Himalayas through the Ganges river system. However, over the last 40 years or more, the discharge of sediment-laden freshwater into the Bay of Bengal from the Ganges River through the Bangladesh part of the Sundarbans has been reduced due to withdrawal of water during the dry period from the Farakka Barrage in 1975 in India. Reduced sediment-laden freshwater discharge through the BSMF river-system since operation of the Farakka Barrage has been attributed to the degradation of the Bangladesh Sundarbans. The result is the two extremes of sediment-laden freshwater discharge experienced at Gorai (a distributary of the Ganges and feeding river to the BSMF) varying from 0.00 to $170 \mathrm{~m}^{3} \cdot \mathrm{s}^{-1}$ during the dry period to about 4000 to $8880 \mathrm{~m}^{3} \cdot \mathrm{s}^{-1}$ (highest of the year) during the wet period (Figure 2). The zero water discharge occurred from January to April in 1995 and in March 1996 and there was only $0.62 \mathrm{~m}^{3} \cdot \mathrm{s}^{-1}$ in January 1997 at Gorai River Station. The east BSMF (Kamarkhali R.) had average surface water discharge of $194.4 \mathrm{~m}^{3} \cdot \mathrm{s}^{-1}$, making the catchments oligohaline (Jikargacha R. about $141.6 \mathrm{~m}^{3} \cdot \mathrm{s}^{-1}$ freshwater discharge is needed to keep salinity of the Khulna Range below 1\%o [40]). The maximum discharge formed a steep slope due to sandbar formation in the Gorai River. The very high water flow in September resulted in erosion of the fragile forestland, which are only 0.9 to $2.11 \mathrm{~m}$ above the mean sea level. The extreme differences of discharge need to be reduced by increasing the sediment-laden freshwater discharge during the dry period, keeping in mind that the freshwater scarcity will increase with time. Decreased nutrient-rich sediment from 400 million to 100 million tons per year prevented transport and uniform dispersal of sediments over mangrove areas [41]. In the Ganges water, the sediment load was 262 million ton/year in 2007 and about $7 \%$ is diverted in to the southern distributaries [42]. Sediment concentration in the Ganges water was high during high discharge and both erosional and depositional processes were active [43].

Sediments supposed to deposit into the BSMF and its southern edge are piled up in the Ganges in the way of huge sandbars, including the Gorai River, due to low discharge of sediment-laden freshwater during dry period (Figure 6A-D). The low discharge caused an increase in salinity of the BSMF as well as hinterlands. The occurrence, depth and salinity of the groundwater and soil-water systems in the tidal swamps and adjoining hinterland are important hydrological factors that can affect mangroves [41]. In the coastal aquifers, the seaward flow of fresh groundwater comes into contact with saline groundwater that has percolated down from overlying bodies of saltwater from the estuaries. Due to pressure differences, a freshwater-saltwater interface is formed: if the pressure is above, then an impeded outflow of freshwater occurs; if it is below, saltwater penetrates the aquifer over great distances [40]. The low freshwater discharge in the Ganges floodplain since 1975 resulted in decreased irrigation and creeping of the saltwater across the BSMF into croplands to the north causing an estimated loss of over several billion US dollars.

The increased salinity and erosion of forestland have been identified as the two major factors for the degradation of the BSMF. The forestland, flora and fauna are threatened and survivability of the Sundarbans is at stake. To reclaim the BSMF, sediment-laden freshwater flow through its intricate river system has been suggested to remain as it was before the operation of the Farakka Barrage in 1975 by implementing the Ganges Barrage Project about $33 \mathrm{~km}$ downstream of Gorai R. (Figure 1A). 
Water-holding capacity of the Ganges R. and its distributaries may be made to increase by dredging in the monsoon and uniformly discharging/transporting the sediment-laden water through Gorai R. into the Passur and Sipsa Rivers in the BSMF and also through Ganges-Padma River to the Meghna estuary [20].

Passur, Sipsa and Apangasia Rivers are life lines of the BSMF, providing freshwater to the BSMF. The Passur R. used to receive freshwater from the Gorai and from the Lower Meghna Rivers through Swarupkati-Kocha River. The Ganges floodplain having perennial water bodies such as "Beel Dakatia" that used to feed the Sipsa River have turned into a moribund delta (Figure 1A). Having low freshwater discharge from the Gorai River, the saltwater is directly transferred to the Passur and Sipsa Rivers through the wide Kunga River estuary, making the surroundings mesohaline. The saltwater intrusion into the two rivers should be blocked by freshwater through Passur and Sipsa Rivers near the mouth of the Kunga River. Similar is the case with the western part of the BSMF, where the Malancha River estuary gives off huge amounts of saline water to Arpangasia and Malancha Rivers, thereby converting the whole area into a saline zone.

The principle of the reclamation process is that the concerned sedimented rivers of the Ganges floodplain north of the Sundarbans will be dredged and feed the BSMF river system with sediment-laden freshwater. The Gorai River, a distributary of the Ganges, is the major river to discharge sediment-laden freshwater into the aforementioned rivers. The river splits into Madhumati R. and the Nabaganga R. (which had $85 \%$ flow before 1975, but in 1990, only 45\% due to sandbar formation). The Nabaganga R. and then Chunkuri, Kalabogi and Kabadak Rivers need to be dredged first, and lastly parts of the Ganges increasing its water-holding capacity and Ganges-Padma up to the confluence of Jamuna River, converting the Ganges River into a freshwater reservoir for the dry period. The government of Bangladesh is exploring the possibility of constructing a barrage in the Ganges River about $33 \mathrm{~km}$ downstream of the mouth of the Gorai River. The cost of dredging may be met from compensation accrued from neighboring countries and also through yearly carbon trading on the Bangladesh Sundarbans; the minimum present value is about US\$280 million per year The prime aim is to discharge sediment-laden freshwater into the forests, which was the way the Sundarbans were formed and naturally maintained since their origin, and thus return to their pre-1975 environment.

This is possible by following lawful negotiations according to the "UN Convention Act 7(1)" to get a water share from international rivers by forming a consortium of India, Nepal, Bhutan and China. The participating countries will contribute the required amount of water from their rivers needed for the Bangladesh Sundarbans during the dry period. The "Mega reclamation project" will create healthy hinterlands and a Ganges floodplain with increased crop production and revenue. Fisheries and other sectors will benefit, and forestland along the coast will be saved from erosion. There will also be a formation of new islands along the coast of Bangladesh, as was found in the last century.

The BSMF appear to have lost an area of over $66 \mathrm{~km}^{2}$ [4] to about $127 \mathrm{~km}^{2}$ [29]. The situation will worsen year after year and the fate of the forestland will be like that of Talpotty Island formed in late 1960s south of the BSMF in the Bay of Bengal near the mouth of Harinbhanga River, now washed away. By reclaiming the Ganges River, its distributaries and tributaries, the BSMF will help to regain agricultural land with decreased salinity by increasing the fresh groundwater of the Ganges floodplain. Fisheries and other sectors will benefit, and forestland along the coast will be saved from erosion, as well as new islands that have formed along the coast of Bangladesh, as was found in the last century. 

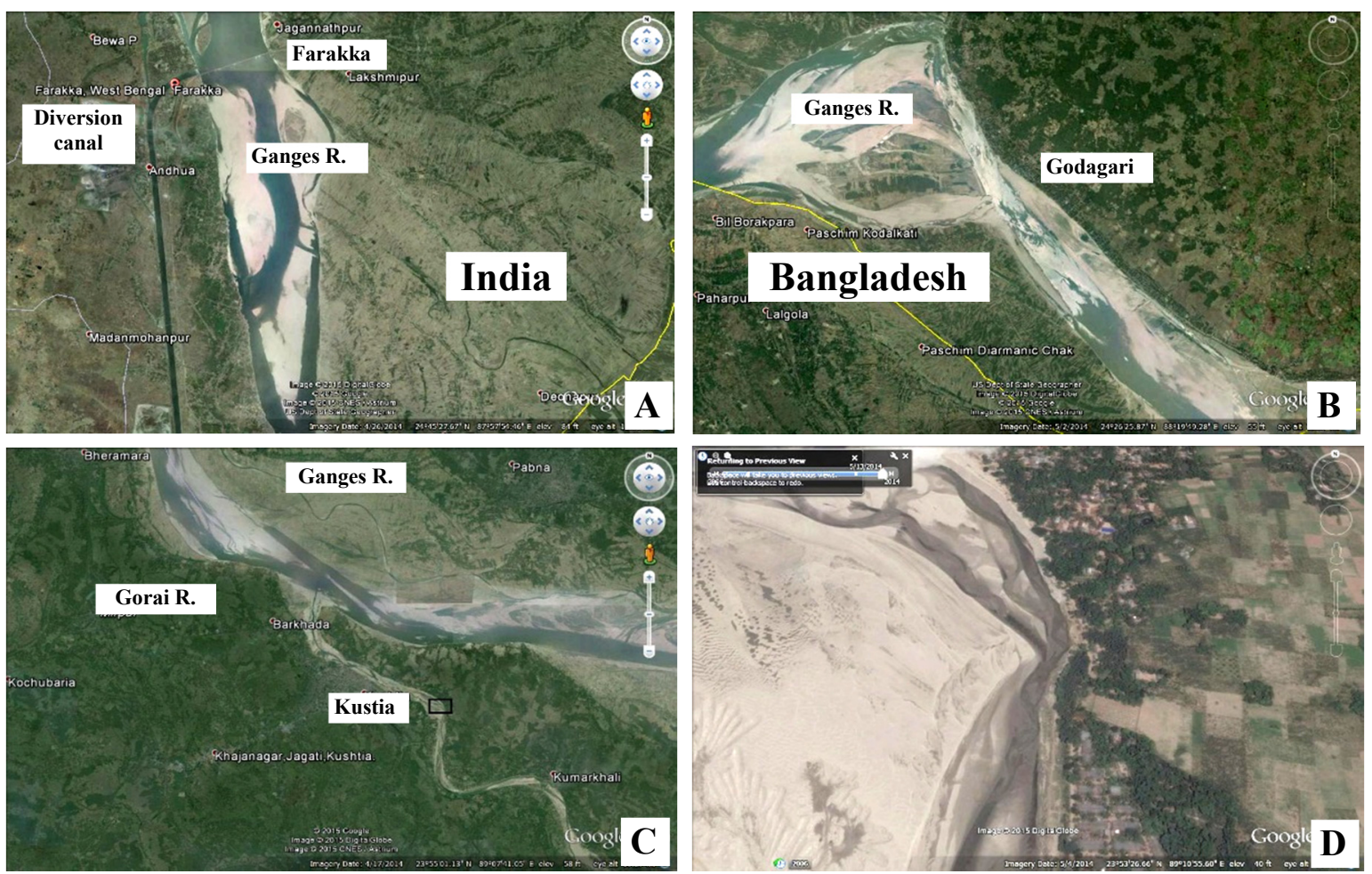

Figure 6. Satellite images of the parts of Ganges River and Gorai River on 15 April 2014. (A) Farakka Barrage, diversion canal and immediate downstream (at $24^{\circ} 47^{\prime} 57.22^{\prime \prime} \mathrm{N} / 87^{\circ} 54^{\prime} 51.79^{\prime \prime} \mathrm{E}$ ); (B) Heavy sandbars in the Ganges River beside Godagai and Jhinaidaha (at $24^{\circ} 05^{\prime} 45.31^{\prime \prime} \mathrm{N} / 88^{\circ} 55^{\prime} 31.04^{\prime \prime} \mathrm{E}$ ); (C) A part of Ganges River and Gorai River (at $23^{\circ} 57^{\prime} 01.21^{\prime \prime} \mathrm{N} / 89^{\circ} 06^{\prime} 52.73^{\prime \prime} \mathrm{E}$. The elbow-like part in the rectangle is enlarged in Figure D; (D) Huge sandbars, East of Kustia in the Garai River making it almost dry (at $\left.23^{\circ} 53^{\prime} 27.43^{\prime \prime} \mathrm{N} / 89^{\circ} 10^{\prime} 16.02^{\prime \prime} \mathrm{E}\right)$. (A,B) images from $18 \mathrm{~km}$ altitude; (C) image from $10 \mathrm{~km}$ altitude and (D) image from $2 \mathrm{~km}$ altitude.)

Bangladesh Sundarban Delta Vision 2050: The Bangladesh Sundarbans have been degraded by overexploitation up until 1989 and, to a great extent, due to low freshwater discharge eventually causing salinity increase and erosion. These factors, along with sedimentation of water courses, pollution from all sources, sea level rise, etc., have great potential for causing serious damage to the delta [36]. To safeguard the Bangladesh Sundarbans, the "Vision 2050 for the Bangladesh Sundarban Delta" aims that:

"by 2050, the Sundarban Delta is rich in biodiversity and highly capable of extending sufficient ecosystem goods and services, to provide sustained social, economic and environmental benefits to the neighbouring communities, nation and beyond, for present and future generations, under a changing climatic scenario" [44].

Remarks: Considering the importance of the Sundarbans, British poet Ted Hughes, a Nobel laureate, wrote on 22 November 1989: 


\section{For things created by God}

For the Sundarbans God created the Royal Bengal Tiger-

Whose eye

Keeps the world in awe.

For the singers God created

Her voice.

For the poet-

His words.

For Bangladesh-

The Sundarbans.

What happens to the singerwho loses her voice.

What happens to the poetwho loses his words?

Bangladesh take careof the Sundarbans.

\section{Conclusions}

The Sundarbans is a deltaic mangrove forest having freshwater influence, formed about 7000 years ago by the deposition of sediments from the foothills of the Himalayas through the Ganges river system. However, the discharge of sediment-laden freshwater into the Bay of Bengal through the Bangladesh part of the Sundarbans Mangrove Forests (BSMF) has been reduced due to a diversion of water during the dry period from the Farakka Barrage in India since 1975. The BSMF receives a mean minimum monthly discharge of 0.00 to $170 \mathrm{~m}^{3} \cdot \mathrm{s}^{-1}$ during the dry period when a minimum of $194.4 \mathrm{~m}^{3} \cdot \mathrm{s}^{-1}$ freshwater discharge is needed to maintain a low saline condition inside the forests. The zero or very low discharge through the forests allows seawater intrusion deep inside the BSMF increasing salinity of water and soil. This affects the growth of Heritiera fomes (sundri), the tallest (at over $15 \mathrm{~m}$ ) and most commercially important plant and also affecting growth and distribution of other mangroves and biota. The high salinity results increase in relatively low-priced plants Bruguiera sexangula, Excoecaria agallocha and Sonneratia apetala. The growing stock of 296 plants per ha in 1959 had been reduced to 144 by 1996. Trend analysis using "Table Curve 2D Programme," reveals a decreased number of 109 plants by the year 2020 .

The Ganges water carries 262 million ton sediments/year and only $7 \%$ is diverted in to southern distributaries recorded in 2007. The low discharge caused deposition of sediments in the Ganges and Gorai Rivers forming huge sandbars that retarded uniform sediment deposition in the forestlands' base as well as the formation of new forestlands for 40 years in the BSMF. The situation has weakened the existing forestlands thereby putting the survivability of the Bangladesh Sundarbans at risk.

The sediment laden freshwater discharge in the wet season (July to October) is high with a mean maximum of about 4000 to $8880 \mathrm{~m}^{3} \cdot \mathrm{s}^{-1}$. The huge discharge in association with the cyclone on some occasions, result in the erosion of the fragile forestlands and formation of a large number of small rivers 
and creeks increasing the marsh and water areas. Landsat Satellite data of the last nearly four decades revealed an estimated loss of 66 to $127 \mathrm{~km}^{2}$ forestlands.

The total carbon reserve in the BSMF in 2010 was measured at about 56 million metric tons, valued at a minimum of US\$280 million per year. The BSMF acts as a natural wall, saving property as well as millions of lives from natural disasters. The value of the ecosystem services is between 273 and 714 million US\$ per year.

The degradation of the Bangladesh Sundarbans has been attributed to reduced sediment-laden freshwater discharge and increased salinity since commissioning the Farakka Barrage in India. To reclaim the Bangladesh Sundarbans the maintenance of sediment-laden freshwater discharge through its river system has been suggested to re-create its pre-1975 forest environment for the growth of $H$. fomes. This may possibly be achieved by proper sharing of the Ganges water from the Farakka Barrage during dry period, forming a consortium of India, Nepal, Bhutan and China, and converting parts or whole of the Ganges River into water reservoir(s). The idea is to implement the Ganges Barrage project about 33 $\mathrm{km}$ downstream, dredging sediments of the entire Gorai River and distributaries in the Ganges floodplain, thus allowing uniform sediment-laden freshwater flow to maintain a low saline environment inside the BSMF and deposition of sediments around forestlands. The system will also create healthy hinterlands of the Ganges floodplain with increased crop production and revenue. The expenditure may be met through carbon trading, as Bangladesh is a signatory of the Copenhagen Accord, UN Framework Convention on Climate Change. Construction of a coal-fired power plant at Rampal only $14 \mathrm{~km}$ away will be the largest threat to the Bangladesh Sundarbans.

We have to keep in mind the remarks of British poet Ted Hughes, a Nobel laureate, “....Bangladesh take care-

of the Sundarbans."

\section{Acknowledgments}

Sincere thanks to Md. Mosaddeque, Chief Engineer and M. Sazzad Hossain, SDE, Bangladesh Water Development Board, Green Road, Dhaka; A.H. Baki, Project Manager, Ganges Barrage Project, Dhaka and M. Kudrat Ali, Project Director, Gorai River Dredging Project, Dhaka for providing a good number of information on the Ganges and Gorai River systems and Ganges floodplain.

\section{Conflicts of Interest}

The authors declare no conflict of interest.

\section{References}

1. Khan, E. The Bangladesh Sundarbans; Wildlife Trust of Bangladesh (WTB): Dhaka, Bangladesh, 2011; p. 168.

2. World Conservation Monitoring Centre. UNEP: Protected Areas Database, 2005. Available online: http://www.wcmc.org.uk/data/database/un_combo.html (accessed on 29 June 2015).

3. Integrated Resources Management Plans for the Sundarbans; Forest Department, Ministry of Environment and Forests: Dhaka, Bangladesh, 2010; Volume I, pp. 1-281. 
4. Giri, C.; Long, J.; Abbas, S.; Murali, R.M.; Qamer, F.M.; Pengra, B.; Thau, D. Distribution and dynamics of mangrove forests of South Asia. J. Environ. Manage. 2014, 100, 1-11.

5. Spalding, M.; Kainuma M.; Collins L. World Atlas of Mangrove; Earth Scan Press: London, UK, 2010.

6. Giri, C.; Ochieng, E.; Tieszen, L.L.; Zhu, Z.; Singh, A.; Loveland, T.; Masek, J.; Duke N. Status and distribution of mangrove forests of the world using earth observation satellite data. Glob. Ecol. Biogeogr. 2011, 20, 154-159.

7. Spalding, M.D.; Blasco, F.; Field, C.D. World mangrove Atlas; International Society Mangrove Ecosystem: Okinawa, Japan, 1997; p. 178.

8. United Nations Environment Programme. Global Environment Outlook Yearbook 2004; United Nations Environment Programme: Nairobi, Kenia, 2004.

9. Mangrove Action Plan. 2005. Available online: http://mangroveactionproject.org (accessed on 29 June 2015).

10. Millenium Ecosystem Assessment. Mille Ecosystems and Human Well-Being: Synthesis; Island Press: Washington, DC, USA, 2005.

11. Duke, N.C.; Meynecke, J.O.; Dittmann, S.; Ellison, A.M.; Anger, K.; Berger, U.; Cannicci, S.; Diele, K.; Ewel, K.C.; Field, C.D. A world without mangroves? Science 2007, 317, 41-42.

12. Food and Agriculture Organization of the United Nations. The World Mangroves 1980-2005; Forestry Paper 153. FAO: Rome, Italy, 2007.

13. Gilman, E.; Ellison, J.; Duke, N.C.; Field, C. Threats to mangroves from climate change and adaptation options: A Review. Aquat. Bot. 2008, 89, 237-250.

14. Chaffey, D.R.; Miller, F.R.; Sandom, K.H. A Forest Inventory of the Sundarbans, Bangladesh; Land Resources Development Centre: Surrey, UK, 1985; p. 196.

15. Curtis, S.J. Working Plan for the Forests of the Sundarbans Division for the Period from 1st April 1931 to 31st March 1933; Bengal Govt. Press: Calcutta, Bengal, 1933.

16. Chaudhuri, A.B.; Choudhury, A. Mangroves of Sundarbans. Volume One: India; IUCN: Bangkok, Thailand, 1994; p. 247.

17. Sanyal, P.; Banerjee, L.K.; Choudhury, M.K. Dancing Mangals of India Sundarbans. J. Indian Soc. Coast. Agric. Res. 1984, 2, 10-16.

18. Rashid, H.E. Geography of Gangladesh; University Press Ltd.: Dacca, Bangladesh, 1977; p. 579.

19. Khan, H.R. Irrigation water requirements in Bangladesh. In River Basin Development; Zaman, M., Biswas, A.K., Khan, A.H., Nishat, A., Eds.; Tycooly International Publishing Ltd.: Dublin, UK, 1983; pp. $150-157$.

20. Aziz, A. Environment: Water Issue. In proceedings of the Annual Botanical Conference 2013, Bogra, Bangladesh, 31 May 2014.

21. Karim, A. The physical Environment. In Mangroves of Sundarbans. Volume 2: Bangladesh; Hussain, Z., Acharya, G., Eds.; IUCN: Bangkok, Thailand, 1994; pp. 11-41.

22. Siddiqi, N.A. Regeneration Status and Influence of Animals on Regeneration in the Sundarbans Mangrove Forests. Ph. D. Thesis, University Dhaka, Dhaka, Bangladesh, 1992.

23. Siddiqi, N.A. Natural regeneration. In Mangroves of Sundarban. Volume Two: Bangladesh; Hussain, Z., Acharya, G., Eds.; IUCN: Bangkok, Thailand, 1994; pp. 75-99. 
24. Hassan, M.M.; Mazumder, A.H.; Islam, A.T.M.; Hossain. A.T.M.E. Soil hydrology and salinity of the Sundarbans in relation to top dying, regeneration and survival of Sundri (Heritiera fomes). In Proceedings of the Seminar on Top Dying of Sundri Trees, Bangladesh Agricultural Research Council: Dhaka, Bangladesh, 1990, pp. 1-11

25. Aziz, A.; Rahman, M.; Ahmed, A. Diversity, distribution and density of estuarine phytoplankton in the Sundarban Mangrove Forests. Bangladesh J. Bot. 2012, 41, 87-95.

26. Samad, M.M.A. Groundwater quality in the coastal areas of Bangladesh. Bangladesh J. Geol. 1986, $5,11-18$.

27. Lugo, A.E.; Snedaker, S.C. The ecology of Mangroves. Annu. Rev. Eco. Syst. 1974, 5, 39-64.

28. Siddiqi, N.A. Mangrove Forestry in Bangladesh; Institute of Forestry and Environmental Sciences, Chittagong University: Chittagong, Bangladesh, 2001; p. 201.

29. Ahmed, A.; Aziz, A.; Khan, A.Z.M.N.A.; Islam, M.N.; Iqubal, K.F.; Nazma, M.; Islam, M.S. Tree diversity as affected by salinity in the Sundarban Mangrove Forests, Bangladesh. Bangladesh J. Bot. 2011, 40, 197-202.

30. Forest Resource Management Plan; Department of Forests, Ministry of Environment and Forests: Dhaka, Bangladesh, 1997.

31. Heining, R.L. Working Plan of the Sundarbans Government Forests, Khulna and 24-Parganas District; Bengal Secretariat Press: Calcutta, Bengal, 1892.

32. Chaffey, D.R.; Sandom, J.H. Sundarbans Forest Inventory Project, Bangladesh. A Glossary of Vernacular Plant Names and a Field Key to the Trees; Overseas Development Administration: Surrey, UK, 1985; p. 23.

33. Islam, A.K.M.N. The algal flora of Sundarbans mangrove forest, Bangladesh. Bangladesh J. Bot. 1973, 2, 411-436.

34. Forestry and Engineering International Ltd. (FORESTAL). Forest Inventory 1958-59 Sundarbans Forests; FORESTAL: Vancouver, BC, Canada, 1960.

35. Nazrul-Islam, A.K.M. Mangrove forest ecology of Sundarban: The study of change in water, soil and plant diversity. In Sustainable Environment: A Statistical Analysis; Ghosh, A.K., Ghosh, J.K., Mukhopadhaya, M.K., Eds.; Oxford University Press: New Delhi, India, 2003; pp. 126-147.

36. Hossain, M.Z. Bangladesh Sundarban Delta Vision 2050: A First Step in Its Formulation-Document 2: A Compilation of Background Information; IUCN, Bangladesh Country Office: Dhaka, Bangladesh, 2014; p. 192.

37. Sundarbans Oil Spill Assessment: Joint United Nations-Government of Bangladesh Mission; Joint UNEP/OCHA Environment Unit: Geneva, Switzerland, 2014; p. 106.

38. Karim, A. Vegetation. In Mangroves of Sundarban. Volume Two: Bangladesh; Hussain, Z., Acharya, G., Eds.; IUCN: Bangkok, Thailand, 1994; pp. 43-74.

39. Islam, M.A., Ameen, Mahmudul-ul., and Nishat, A. (Eds.). Red List of Threatened Animals of Bangladesh; IUCN_-The World Conservation Union: Dhaka, Bangladesh, 2000; p. 54.

40. Karim Z.; Shaheed, S.M.; Salauddin, A.B.M.; Alam, N.K.; Hoq, A. Coastal Saline Soils and Their Management in Bangladesh; Soil and Irrigation Publication No. 8. BARC: Dhaka, Bangladesh, 1982.

41. Chapman, V.J. Mangrove Vegetation; J. Cramer: Vaduz, Liechtenstein, 1976.

42. Rice, S.K. Suspended Sediment Transport in the Ganges-Brahmaputra River System, Bangladesh. Master's Thesis, Department of Oceanography, Texas A. \& M. University, 2007; p. 81. 
43. Islam, M.R.; Begum S.F.; Yamaguchi Y.; Ogawa K. The Ganges and Brahmaputra Rivers in Bangladesh: Basin Denudation and Sedimentation; First published online: 14 December 1999; John Wiley: Hoboken, NJ, USA, 2001; p. 9.

44. Bangladesh Sundarban Delta Vision 2050: A first Step in its Formulation-Document 1: The Vision; IUCN, Bangladesh Country Office: Dhaka, Bangladesh, 2014; p. 23.

(C) 2015 by the authors; licensee MDPI, Basel, Switzerland. This article is an open access article distributed under the terms and conditions of the Creative Commons Attribution license (http://creativecommons.org/licenses/by/4.0/). 